\title{
The Septuagint translation as the key to the etymology and identification of precious stones in the Bible
}

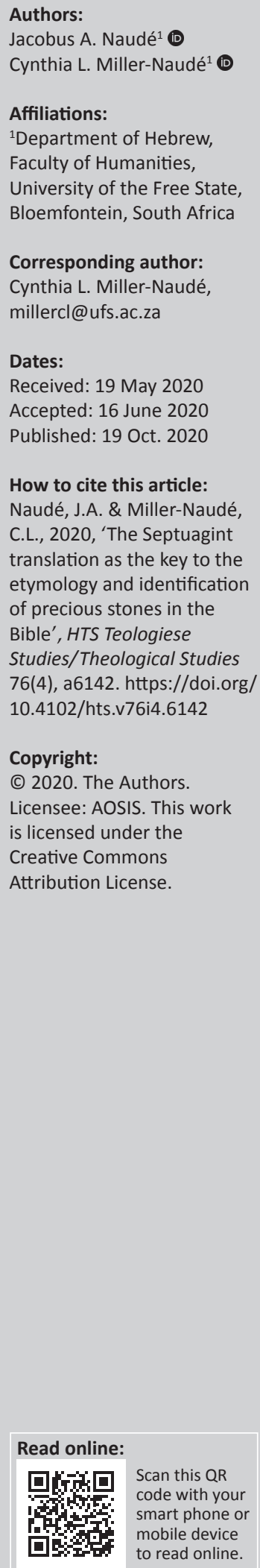

In the ancient world, precious stones (valuable stones and hard substances excluding gold, silver and copper) were distinguished in terms of appearance (beauty, colour), function (durability) and cost (rarity). As a result, there is considerable difficulty in determining how to correlate the inventory of lexical terms referring to precious stones in the ancient Near East with modern mineralogical identifications. In this article, the etymology and identification of precious stones in the Bible are revisited using editorial theory and complexity thinking. The starting point for lexicographical identification is the breastpiece of the high priest (Ex 28:17-20; 39:10-14) with its 12 precious stones and the translation of the Hebrew terms in the Septuagint. In the light of the considerable writings in the Hellenistic world on precious stones, especially Pliny's Naturalis Historia and Theophrastus' On Stones, the Septuagint provides the key for the etymology and identification of the precious stones in both the Old Testament and the New Testament.

Contribution: The Septuagint translation of the precious stones in the high priest's breastpiece is the Rosetta Stone for the identification all of the precious stones in the Hebrew Bible and New Testament. The subsequent translations of the terms indicate changes or substitutions of referents and their meanings.

Keywords: Septuagint; Breastpiece of high priest; Exodus 28:17-20; Exodus 39:10-14; Pliny Naturalis Historia; Theophrastus On Stones; Precious stones; Editorial theory; Complexity Thinking; Lexicography.

\section{Introduction}

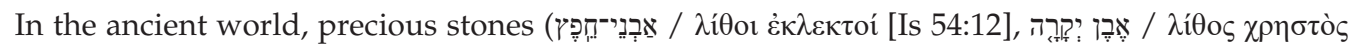

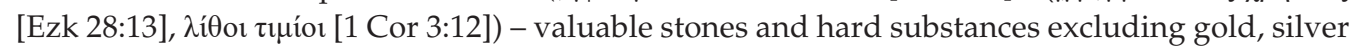
and copper - were distinguished in terms of appearance (beauty, colour), function (durability) and cost (rarity) (Bauer 1968:106-110; Louw \& Nida 1988:24). The precious stones are named according to colour, usage or place of origin. To relate these stones to the present mineralogical classification is problematic and various identifications have been proposed, mainly influenced by the writings of Theophrastus and Pliny the Elder. Some of the terms in modern languages are

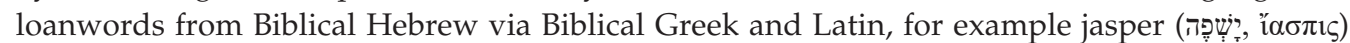

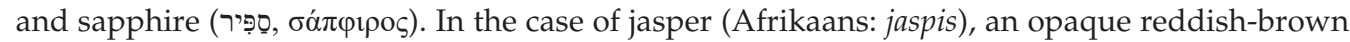
variety of compact quartz, the referent of the term in modern languages is the same as in Biblical Hebrew and Biblical Greek. However, in the case of the term sapphire (Afrikaans: saffier), in modern languages it refers to a transparent precious stone, typically blue, which is a variety of corundum (aluminium oxide), but the related terms in Biblical Hebrew and Biblical Greek denote lapis lazuli (Afrikaans: lasuursteen), which is an opaque blue stone consisting largely of lazurite (Gove 1966:1271; Hoad 1986:246, 417; McKean 2005:902, 953, 1504). A similar shift in referents of plant terms, for example the terms 'cedar' and the so-called 'hyssop' (which actually refers to marjoram in Biblical Hebrew and Biblical Greek) occurs as loanwords from Biblical Hebrew and Biblical Greek into modern languages (Miller-Naudé \& Naudé 2018; Naudé \& Miller-Naudé 2018; Naudé, Miller-Naudé \& Makutoane forthcoming). Words that resemble one another in two languages often do not mean the same thing; they are the so-called 'false friends' (Crystal 1997:349). The translators of the Septuagint translated the Biblical Hebrew terms for precious stones into Greek in terms of their interpretation and understanding of precious stones. Thereafter, the Septuagint was used and interpreted by later Greek authors in terms of their (new) context, for example Josephus and the authors of the New Testament (e.g. Rv 21). This state of affairs poses a problem for modern translators who must determine the referents of the precious stones in biblical times. 
The aim of this article is to revisit the identification and classification of precious stones in the Bible within a complexity theoretical approach. ${ }^{1}$ Previous studies in this regard are reductionist in that they reached their conclusions based on either the Hebrew terms, for example Harrell, Hoffmeier and Williams (2017), Quiring (1954) or the Greek terms, for example Harrell (2011) and Reader (1981). The same pertains to the various Hebrew and Greek dictionaries, where various terms of precious stones have sometimes the same referent. For example, Brown, Driver and Briggs (1979:448) translate the Biblical Hebrew term However, Brown et al. (1979:240, 1797) suggest the same

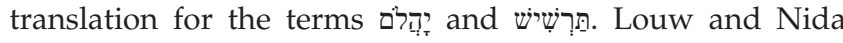
(1988:24-26) are an exception in this regard, where the precious stones are represented together in a single system. Unfortunately, the dictionary by Louw and Nida (1988:2426) is still reductionist, because other interacting systems (e.g. diachronic changes in the referents of terms) are not taken into account.

The article is organised as follows: In the next section the theoretical approach and methodology will be outlined, followed by an analysis of the precious stones to determine their identification and their impact on word origins for precious stones in modern languages. Materials of organic origin (e.g. the pearl, red coral and amber) are not considered in this article; some of them are treated in Naudé and MillerNaudé (2019:189-193, forthcoming).

\section{Theoretical approach and methodology Knowledge of precious stones}

The oldest known treatise on minerals (On Stones) was written by Theophrastus (372/369-288/285 BCE) around 300 BCE (Theophrastus [1916] 1999). The treatise seems to be an attempt to classify minerals on the basis of Aristotelian principles and is the first attempt to study mineral substances in a systematic way (Caley \& Richards 1956:9). He classified minerals as metals, stones and earths. He distinguished 'metals' by their metallic lustre and so included many sulphides, whereas 'earths' were those that collapsed when immersed in water (Caley \& Richards 1956:45-46). The classification or system resulting from this method of treatment is logical, being grounded upon superficial

\footnotetext{
1.One anonymous reviewer remarked that this enterprise is futile: "Unless an 1.One anonymous reviewer remarked that this enterprise is futile: Unless an
archaeologist digs up an ancient museum from the Holy Land with the 12 objects archaeologist digs up an ancient museum from the Holy Land with the 12 objects
with a tag attached to each of them with a Hebrew name inscribed, we are bound with a tag attached to each of them with a Hebrew name inscribed, we are bound
to keep groping in the dark, when we have no description in the Bible indicating physical features of each of the stones. The LXX translators, as they worked in the pre-Christian period, may have been able to take readers of their translation outdoors and point to stones lying about there "Look, that is here is $\square$ TुK and so on"'. This viewpoint presupposes that all valid knowledge must be established empirically and is thus positivist. It is further naïve in terms of the conduct of scientific inquiry, as well as the translation process in reality, which is complex. As explained previously (Naudé \& Miller-Naudé 2018:4-5), in our approach we are steering away from the modernist tendency to reduce explanation to a single dimension of reality as well as the postmodernistic fragmentation to a single dimension of reality as well as the postmodernistic fragmentation of reality. We embrace complexity (the lingual units or texts [oral and written] are too multifaceted to be adequately conceptualised in terms of only one elementary concept or idea), interconnectedness (any element or sub-system in the system is affected by and affects several other elements or sub-systems), dynamism (everything changes all the time) and emergence (the appearance of a new state at a level of organisation higher than the previous one).
}

appearance and behaviour rather than upon any concept of chemical composition (Caley \& Richards 1956:9). According to Caley and Richards (1956:10), from a scientific standpoint this little treatise is much better than the other ancient and medieval works on minerals and 'for almost two thousand years this treatise by Theophrastus remained the most rational and systematic attempt at a study of mineral substances'.

Another ancient source is Naturalis Historia of Pliny the Elder (23/4-79 CE) containing an extensive discussion on Mineralogy and Metallurgy and their use in the arts (Books xxxiii-xxxvii). Although Pliny referred to 20 previous Greek writers on precious stones (of which the one by Theophrastus was the only one to survive) (Bostock \& Riley 1857:466-467) and mentioned about ten times as many kinds of rocks or minerals as Theophrastus (Caley \& Richards 1956:9), he does so in a much less critical and systematic fashion. To name the newly discovered species of precious stones, Pliny used many times existing terms, for example the term smaragdus was used for 12 varieties of green precious stones (Bostock \& Riley 1857:408-411), whereas Theophrastus has only one referent for $\sigma \mu \alpha \dot{\alpha} \rho \alpha \gamma \delta$ o $($ Caley \& Richards 1956:19, 23). The implication is that the referents of the terms used by Pliny are different than those used in earlier texts.

The modern editions of the treatise of Theophrastus, for example the one by Caley and Richards (1956), provide translation and annotated commentary. The commentary provides reinterpretation of the various stones in terms of modern mineralogy and jewellery, as well as in terms of especially Naturalis Historia Books xxxiii-xxxvii (Mineralogy and metallurgy and their use in the arts) of Pliny the Elder (23/4-79 CE) (e.g. Caley \& Richards 1956:97-102 on $\sigma \mu \alpha \dot{\rho} \alpha \gamma \delta \delta \varsigma)$. These interpretations have dominated views on the identification of precious stones and influenced lexicography and Bible translation. The environmental world view of Theophrastus and Pliny is far removed from the environmental world views represented in the Hebrew Bible and the Septuagint. Some of these interpretations are questioned in this article as not reflecting the insights of the translators of the Septuagint.

In the 13th century (after $1248 \mathrm{CE}$ ), Albertus Magnus wrote his Book of Minerals (Mineralia). Magnus based his mineralogical model on the four causes distinguished by Aristotle: the material cause (the matter of which minerals are made), the efficient cause (the process by which minerals are made), the formal cause (the formative power) and the final cause (purpose). The material cause is the basis of his general classification into three groups: stones (Books I and II), metals (Books III and IV) and 'intermediates' (Book V) (Magnus 1967:xxxii). The formative power that descends from the heavens through the influence of the stars determines the particular kind of mineral that will be formed at any particular time and place (Magnus 1967:xxxii). Magnus then considers 'accidental' properties (texture, colour, hardness, fissility or cleavage, density, structure and fossils), which occur in a specific stone and not in another (Magnus 
1967:xxxiii). The work of Albertus Magnus influenced the field until Georgias Agricola (1490-1555), the father of mineralogy, in the 16th century (Magnus 1967:vii).

In scientific mineralogy, precious stones are regarded as minerals and are classified accordingly (Bauer 1968:106). The modern method of the identification and classification of minerals relies upon the determination of their composition and position of different elements in the crystal structure. X-Ray Diffraction, which was developed in 1917, is used to determine the atomic structures of minerals (Bauer 1968:vii, 7). The stones of a specific mineral can be of different colours, and in some cases the colour is regarded as non-essential in the scientific classification of minerals (Bauer 1968:107). Of the more than 5514 currently valid species according to the International Mineralogical Association (IMA) from September 2019 (https: / / www.ima-mineralogy.org/Minlist. $\mathrm{htm})$, less than 100 are used as precious stones and about 16 are well known, namely beryl, chrysoberyl, corundum, diamond, feldspar, garnet, jade, lazurite, olivine, opal, quartz, spinel, topaz, tourmaline, turquoise and zircon. Some of these minerals provide more than one type of precious stone; beryl, for example, provides emeralds and aquamarines. The scientific perspective of modern mineralogy is one aspect considered in this article.

Another aspect involves a determination of which precious stones are attested from the ancient Near East. Inscribed seals in cornelian, chalcedony, jasper, agate, onyx, rock crystal, hematite, jade, opal and amethyst from biblical times have been found in Israelite archaeological sites (Diringer 1958:218). Concerning jewellery in Ancient Egypt, Romano (1995:1606) named lapis lazuli (imported via Mesopotamia from northeastern Afghanistan), pale blue or green-blue turquoise (from the copper mines in Sinai) and red carnelian (from Aswan and Lower Nubia) as valued above all others for their rarity and beauty. Other colourful minerals, for example amethyst, bluish white chalcedony, feldspar, red garnet, red jasper, shiny black obsidian, milky white quartz, hematite and steatite (soapstone), were attested in Egyptian jewellery (Aldred 1978:16-18, 113-126; Romano 1995:1606, 1608). From the fifth millennium BCE, Egyptian jewellers manufactured less costly artificial substitutes such as Egyptian faience (from Predynastic Period until the Islamic period) and glass (introduced in the New Kingdom (1550 1069 BCE) (Romano 1995:1606). The jewellery discovered in ancient Western Asia since the seventh millennium BCE contains stones of lapis lazuli, carnelian, agate, chalcedony, malachite, hematite, turquoise, obsidian and steatite (Bahrani 1995:1635-1645; Platt 2003:197-204). This evidence refutes the claim that certain precious stones were not known during biblical times, for example jasper (see, e.g. Caley \& Richards 1956:107-108). It is important to note that the precious stones represented by inscribed seals are not so different from the above-mentioned list of modern varieties of gemstones.

It is further important to make the observation that in ancient times, only stones of less hardness such as agate, opal, jasper, onyx and chalcedony could be polished, but then they retained their natural shape. These gemstones may be cut with a rounded upper surface (cabochon) and a flat underside and polished on sandstone (Bauer 1968:81-85, 521). Stones of higher hardness (like diamonds and rubies) could not be shaped before the invention of the carborundum saw about 1700 CE (Bauer 1968:72-79). It is then likely that the first mentioned group of stones (which could have been shaped in biblical times) would be presented in the biblical texts, rather than the latter group.

In contrast to the system of classification of precious stones used by mineralogists, the classification adopted by jewellers is different and is more or less arbitrary in nature (Bauer 1968:107). For jewellers, the identification depends largely on colour, whereas chemical composition has a less prominent role (Bauer 1968:107). As a result, what a mineralogist considers an essential feature may not have the same importance in the classification of a jeweller and vice versa. Other systems include the frequency (or rarity) of their occurrence in nature, their value or a classification as precious stones or jewels and semi-precious stones. According to their types, stones can be opaque, translucent and transparent.

However, both the scientific and commercial usage agree by classifying stones according to their essential characteristics and giving them scientific and commercial names (Bauer 1968:106). For example, the term 'chalcedony' is a commercial term for quartz that is fine-grained and not a general geological term. Quartz has a composition of $\mathrm{SiO}_{2}$; Agate, onyx, carnelian are all made up of quartz $\left(\mathrm{SiO}_{2}\right)$. The main difference is either colour or texture. Agate has rings and is usually grey and white, onyx is black in colour and carnelian is the orange version (Bauer 1968:106). They are considered by the jeweller, in spite of their mineralogical identity, as distinct and separate stones, and as such are distinguished by special names as was done in ancient times. This observation forms a basic assumption in our project.

\section{Lexicography and the nature of the information on precious stones}

Aitken (2014:2, 6-10) stated that as the Greek of the Hellenistic and Roman periods is not well represented in current reference works, the Greek of the Septuagint is misleadingly interpreted through evidence from other periods of the language. For example, the Septuagint dictionary of Lust et al. (2003) relies on the classical Greek lexical information in Liddell, Scott and Jones (1968) for their meanings of words in the Septuagint. According to Aitken (2014:10), Muraoka (2009) is a major advance from its predecessors, 'because his aim has been to analyse each word in context'. The claim is that it 'is not dependent on any other Septuagint lexicon but is based on a fresh lexical analysis of the material' (Lee 2010:117). Chamberlain (2011) supplemented Bauer et al. (2000) in instances where words in the Septuagint have additional meanings, where Bauer et al. (2000) lack the Septuagint word or where the whole pattern of usage differs substantially from that of the New 
Testament. However, the Greek dictionaries, including Muraoka (2009) and Chamberlain (2011), are reductionist because the nature of their focus is primarily linguistic (Naudé \& Miller-Naudé 2018:4). The same pertains to Hebrew lexicography as was shown by Naudé and MillerNaudé (2018:2-4). Assuming that the meaning of a word is more than linguistic information as such and that meaning also relates to a cognitive and cultural representation of the word implies that a relationship between images and words on the one hand and experience (cognition) of the language user on the other must be established in an attempt to find cultural explanations for these conceptions (Naudé \& MillerNaudé 2018:4).

The reductionist strategy of the Hebrew and Greek dictionaries resulted in an incorrect identification of precious stones. As was demonstrated in Naudé and Miller-Naudé (2018:4-6), words and their meanings are too multifaceted to be adequately conceptualised in terms of only one elementary concept or idea, but a whole set of simultaneous, interacting elements and forces, such as cognition, consciousness, experience, human interaction, society, culture, history, etc., force the view that words and their meaning comprise a complex phenomenon in which the effects of these components are connected (Ellis \& Larsen-Freeman 2009; Larsen-Freeman \& Cameron 2008; Marais 2014; Naudé \& Miller-Naudé 2018:1-13). The implication of complexity thinking is that when the meaning of a word is to be determined, the full range of information must be taken into consideration including its history, which is neglected in present Greek dictionaries (Lee 2004:66-74).

Aitken (2014:3-6) provided three features of the vocabulary of the Septuagint (300 BCE), namely that (1) it represents the vernacular of the time (see also Horsley 1984:393-403), (2) there are 1900 or $20 \%$ new words or neologisms in the Septuagint and (3) the presence of new or extended meanings for words was already attested in Greek before the time of the Septuagint. As was argued in Miller-Naudé and Naudé (2018:1-12), three further aspects need to be taken into account concerning the vocabulary of the Septuagint. Firstly, research on the Septuagint has been driven primarily by the needs of textual criticism either as a search for the Vorlage or Urtext (earliest text) or as a search for the best or most authoritative final text; these endeavours are reductionist. Secondly, within the perspective of the larger field of Editorial Theory, texts must be studied in their own right as integral parts of historically existing manuscripts and must be interpreted in the light of the context of the manuscript and its historical usage (Lied \& Lundhaug 2017). Thirdly, the Septuagint is a translation of a Biblical Hebrew incipient text, which implies that translation choices (or strategies) were applied by the translators of each book, which would influence the word choice. Cultural values of the translators influenced those choices and they shaped the metaphorical and symbolic meaning, for example, of precious stones within their context. Our view is therefore that the choices of the translators/editors/scribes must be studied in the light of the context of the specific manuscript under discussion as well as the alterity of the Israelite/Hebrew cultural background.

Languages are always in a state of change. One change pertains to vocabulary with the arrival of new words and the loss of old ones. Crystal (1997:332) stated that the vast majority of new words were borrowings from other languages as loanwords and loan translations (calques). Other changes concerning semantic change include extension (a word widens its meaning), narrowing (a word becomes more specialised in meaning), shift (a word moves from one set of circumstances to another), figurative use (a shift in meaning based on an analogy or likeness between things), amelioration (a word loses an original sense of disapproval) and pejoration (a word develops a sense of disapproval) (Crystal 1997:332).

The importance of etymology is to trace the development of form and meaning over an extended period of time for each word in a language and to determine from what other language(s) the form may have derived (Landau 2001:127-134). As most of the terms of precious stones in modern languages such as English and Afrikaans are loanwords from Greek, it is important to trace the history of these terms, especially in terms of their usage in Greek and specifically the Septuagint. As the Septuagint is a translation of a Hebrew text, the relation between the translation of the terms in the Septuagint and their usage in the Hebrew text must be investigated within complexity thinking as expressed here. The usage of the terms in the New Testament text must then be compared. On the basis of this information, identifications of the precious stones in the Bible can then be provided. Using the results of this enterprise will disentangle modern views that there is no relation between the identification of modern terms and the referent of the biblical usage of the terms. The meaning of certain terminology can stay stable for centuries. ${ }^{2}$ The Modern Hebrew dictionary of Alcalay (1963-1965) is therefore consulted to provide further evidence in this regard.

\section{An analysis of the precious stones The pivotal role of the Septuagint}

The Hebrew Bible mentions 12 precious stones arranged in four rows of three each on the high priest's breastpiece in two identical lists in Exodus 28:17-20 and 39:10-13. ${ }^{3}$ Nine of these

\footnotetext{
2.As response to Barr (1961), Fensham (1971:53-54) discarded the uncautious usage of etymology and defended a responsible usage of etymology on the basis that of etymology and defended a responsible usage of etymology on the basis that
despite differences between related languages a great variety of words still have the despite differences between related languages a great variety of words still have the
same meaning or almost the same meaning. He used 'book' as an example, which same meaning or almost the same meaning. He used 'book' as an example, which
has the same meaning in English. Afrikaans and Dutch. The meaning of certain has the same meaning in English, Afrikaans and Dutch. The meaning of certain terminology can stay stable for centuries; for example, religious terminology coined at the Synod of Dort in 1618 is used with exactly the same meaning in the modern world in Dutch Reformed Churches after 400 years. The same pertains to religious
terminology (e.g. sacrifice) and legal terminology (e.g. treaty and covenant) in the ancient world.

3.In this article, the following text editions are used: Biblia Hebraica Stuttgartensia (1997) for the Hebrew Bible; Göttingen Septuaginta where available and Rahlfs (2008), Hanhart (1979, 1983, 2006), Wevers (1974-1991) and Ziegler (1965, 1982 1983, 2006) for the Septuagint; Weber and Gryson (2007) for the Vulgate; Clark (1984), Cohen (1992), the Comprehensive Aramaic Lexicon Project, Levy (1986) and Sperber (1992a, 1992b) for the targumim; Mulder (1993), Ter Haar Romeney and Van Peursen (2016) for the Peshitta and Aland et al. (2012) for the New Testament.
} 
TABLE 1: Order of precious stones in LXX compared with MT-Exodus and MT-Ezekiel.

\begin{tabular}{|c|c|c|c|}
\hline & $\begin{array}{l}\text { MT-Exodus 28:17-20; } \\
\text { MT-Exodus 39:10-14 }\end{array}$ & $\begin{array}{l}\text { LXX-Exodus 28:17-20; } \\
\text { LXX-36:17-20; } \\
\text { LXX-Ezekiel 28:13 }\end{array}$ & MT-Ezekiel 28:13 \\
\hline \multirow[t]{3}{*}{ Row 1} & אדֶדם & 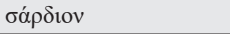 & אדֶ \\
\hline & 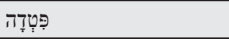 & 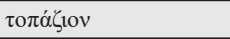 & 勿 \\
\hline & בדרְקֶת & $\sigma \mu \alpha ́ \rho \alpha \gamma \delta \circ \varsigma$ & יָדהלם \\
\hline \multirow[t]{3}{*}{ Row 2} & נפכָך & $\alpha \ddot{\alpha} v \theta \rho \alpha \xi$ & תמרְשׁישיש \\
\hline & סַפְּיר & 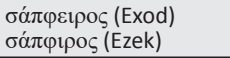 & שהָם \\
\hline & אינהלםם & $i \alpha \sigma \pi 1 \varsigma$ & , \\
\hline \multirow[t]{3}{*}{ Row 3} & לֶשֶם & 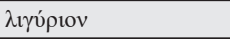 & סַפְּיר \\
\hline & שֶׁבוֹ & $\dot{\alpha} \chi \alpha \dot{\alpha} \tau \eta \varsigma$ & \\
\hline & אַחְלְלָה & $\dot{\alpha} \mu \dot{\varepsilon} \theta v \sigma \tau \circ \varsigma$ & נִפֶ๊ \\
\hline \multirow[t]{3}{*}{ Row 4} & תמרְשׁיש & $\chi \rho v \sigma o ́ \lambda_{1} \theta_{0 \varsigma}$ & בדרקתת \\
\hline & שהםם & $\beta \eta \rho \cup ́ \lambda \lambda$ ıоo & \\
\hline & זָישָׁפה & 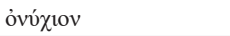 & \\
\hline
\end{tabular}

Note: Grey-shaded areas indicate identity (or close similarity) of stones with the lists in MT-Exodus and/or MT-Ezekiel.

MT, Masoretic Text; LXX, Septuagint.

precious stones reappear in the Tyrian king's 'covering' in Ezekiel 28:13 in three groups of three, although the order is slightly different from Exodus. In the Septuagint of Exodus, the same 12 precious stones appear, but with an order that varies slightly from the Hebrew. In the Septuagint of Ezekiel, there are 12 precious stones rather than 9 as in the Hebrew, and the order of stones in LXX-Ezekiel is identical to that in LXX-Exodus. As indicated in Table 1 and as will be further argued here, the LXX list of stones correlates with the Hebrew lists in Exodus in nine instances (as indicated by grey shade in Table 1). It is clear that i $\alpha \sigma \pi ı \varsigma$ (jasper) cannot possibly

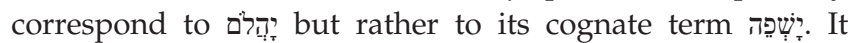
therefore follows that óvóxiov should not be considered to be

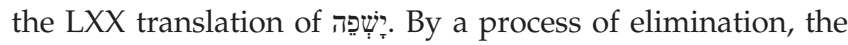
final pairs - שنהם and $\beta \eta \rho v ́ \lambda \lambda$ iov - also do not correspond. For these three word pairs, then, the Greek term should not be considered as a translation of the Hebrew term. Rather, as argued in Miller-Naudé and Naudé (2020), the Septuagint translator(s) of Exodus has re-arranged the order of the stones in his rendering of the breastpiece of the high priest to highlight the symbolic values of the stones rather than their connection to the 12 tribes. The agency of the Septuagint translator(s) can further be seen in the fact that the translator(s) of LXX-Ezekiel has normalised the list of stones in two ways: firstly, by adding back the three stones that are present in the Hebrew of Exodus but missing in the Hebrew of Ezekiel; and secondly, by harmonising the list of stones in Ezekiel to reflect the order of the list in Exodus. These changes by the Septuagint translators do not reflect a different Hebrew Vorlage but rather translation strategies for theological and ideological purposes.

By understanding the translation strategies of the Septuagint translators in rendering the lists of precious stones, it becomes clear that for nine stones the Greek term that correlates with the Hebrew term is a translation equivalent and can thus be used to better understand the referent of the Hebrew term. For an additional stone, namely Greek i $\alpha \sigma \pi ı \varsigma$ which correlates with the Hebrew in the Ezekiel list but not in the Exodus lists, can safely be considered a translation equivalent because of the clear etymological link between them (see Compact quartz below). As will be
TABLE 2: Comparison of the precious stones in Revelation 21:19-20 and the LXX.

\begin{tabular}{|c|c|c|}
\hline $\begin{array}{l}\text { LXX-Exodus; } \\
\text { LXX-Ezekiel }\end{array}$ & $\begin{array}{l}\text { Revelation 21:19-20 } \\
\text { (LXX order) }\end{array}$ & $\begin{array}{l}\text { LXX-Exodus; LXX-Ezekiel } \\
\text { Terms replaced in Revelation 21:19-20 }\end{array}$ \\
\hline 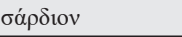 & 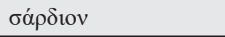 & \\
\hline 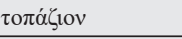 & 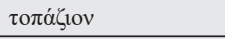 & \\
\hline$\sigma \mu \alpha \dot{\alpha} \rho \gamma \delta \delta \sigma$ & 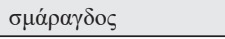 & \\
\hline$\alpha{ }^{2} v \theta \rho \alpha \xi$ & $\chi \rho v \sigma o ́ \pi \rho \alpha \sigma o \varsigma$ & $\ddot{\alpha} v \theta \rho \alpha \xi$ \\
\hline 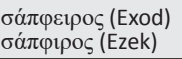 & 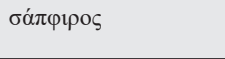 & 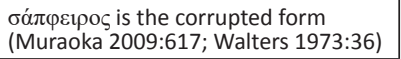 \\
\hline ï $\alpha \sigma \pi \mathrm{s}$ & $i \alpha \sigma \pi \mathrm{s}$ & \\
\hline$\lambda$ iүúpiov & 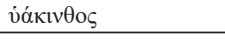 & $\lambda$ irv́pıov \\
\hline $\dot{\alpha} \alpha \dot{\alpha} \tau\rceil$ & $\chi \alpha \lambda \kappa \eta \delta \dot{\omega} v$ & $\dot{\alpha} \chi \alpha \dot{\alpha} \tau \eta_{\varsigma}$ \\
\hline$\dot{\alpha} \mu \varepsilon \dot{\theta} \theta 0 \sigma \tau \mathrm{\sigma} \varsigma$ & 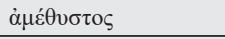 & \\
\hline 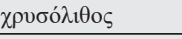 & 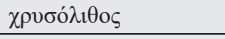 & \\
\hline$\beta \eta \rho v ́ \lambda \lambda$ เоv & $\beta \eta ́ \rho v \lambda \lambda \circ \varsigma$ & $\begin{array}{l}\beta \eta \rho v ́ \lambda \lambda_{10} \text { is the diminutive form } \\
\text { (Liddell \& Scott [1871] 1976:314) }\end{array}$ \\
\hline ỏvóð1ov & $\sigma \alpha \rho \delta \operatorname{vov}^{\prime} \xi$ & 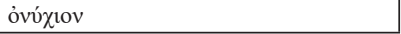 \\
\hline
\end{tabular}

Note: Grey-shaded areas indicate identity (or close similarity) of stones with the lists in the Septuagint and Revelation 21:19-20.

LXX, Septuagint.

demonstrated below, the referential identity between the two terms is absolutely solid. The lists of the precious stones on the breastpiece of the high priest and the canopy of the king of Tyre thus function as a kind of Rosetta Stone by providing the key to the identification of the precious stones in the Bible. The Septuagint by virtue of both its influence on other ancient translations as well as the presence of Greek treatises on stones provides the foundation for the analysis.

The pivotal role of the Septuagint lists in Exodus and Ezekiel becomes clearer when consideration is taken of the list of foundation stones in Revelation 21:19-20, which represent the 12 apostles (see Table 2).

Eight stones from the breastpiece of the high priest as rendered by the Septuagint translators are identical to the stones in the wall of the New Jerusalem. Four stones, however, are different. It will be demonstrated here that the four new stones in Revelation 21:19-20 relate to a changing social and cultural situation with respect to the introduction of new stones in society in the Roman period and a devaluing of other stones. However, the new stones exhibit qualities that relate them to the stones in the Septuagint that they replace. The Septuagint rendering of the stones of the breastpiece of the high priest thus continues to exert influence in the New Testament as an incipient text, which is re-interpreted for a new understanding of the foundational role of the apostles in New Jerusalem.

In the following sections, the precious stones are grouped together with respect to their mineralogical classification and characteristics and then considered with respect to their etymological derivation and history, their archaeological distribution and their textual representations.

\section{Quartz}

Quartz $\left(\mathrm{SiO}_{2}\right)$ can be distinguished in three groups: compact quartz, crystallised quartz and chalcedony. The different types of quartz are often confused with one another, especially in the chalcedony group (Bauer 1968:471-524). 


\section{Compact quartz}

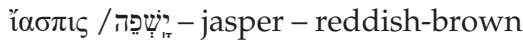

LXX Exodus 28:18, 36:18, LXX Ezekiel 28:13, LXX Isaiah 54:12,

MT Exodus 28:20, 39:13, MT Ezekiel 28:13

Revelation 4:3, 21:11, 18, 19

As stated above, the Greek term ' $\alpha \sigma \pi \mathrm{s}$ is a loanword from Semitic (Akkadian (y)ašpū, Arabic yašb, Syriac yašfēh and Biblical Hebrew (and French) as 'jasper' with the same referent (Noonan 2019:113-114; Pickett 2002:742). The Hebrew (Brown et al. 1979:448; Clines 1998:339; Köhler \& Baumgartner 2001:449), Greek (Abbott-Smith 1937:212; Arndt \& Gingrich 1957:369; Bauer et al. 2000:465; Liddell et al. 1968:816; Liddell \& Scott [1871] 1976:325; Lust et al. 2003:283; Montanari 2015:962; Muraoka 2009:336) and Latin (Lewis \& Short [1879] 1945:874) dictionaries and scholars such as Quiring (1954:209-210) and Cooper (1928:48) translate the Hebrew

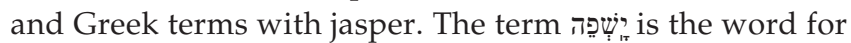
'jasper' in Modern Hebrew (Alcalay 1963-1965:972).

Jasper (Afrikaans: jaspis) is an opaque reddish-brown cryptocrystalline variety of compact quartz $\left(\mathrm{SiO}_{2}\right)$. It is insightful that the translator(s) of LXX Isaiah 54:12 used i $\alpha \sigma \pi \mathrm{k}$ to translate white microcrystalline variety of chalcedony and very similar to jasper, because a Greek term was lacking at that time. It is only later in Revelation 21:19 that the term $\chi \alpha \lambda \kappa \eta \delta \omega v$, which is a hapax legomenon in Koine Greek, is used to refer to common chalcedony. Harrel (2011:156) identifies $\imath^{\alpha} \alpha \pi \iota \varsigma$ initially as 'probably some form of "Green Microcrystalline Quartz" but possible "Amazonite"', but later redefined it as 'probably multicoloured, patterned agate or jasper' (Harrell et al. 2017:29-30). Bauer (1968:499) stated that the 'colours most commonly seen in jasper are brown, yellow and red; green is fairly common, but blue and black are more rare'. Although Quiring $(1954: 209,211)$ mentioned red as a prominent colour of jasper, his view was that the purple variety was the most precious. Cooper (1928:48) has the opinion that in the biblical texts the green colour must be prominent. Jasper is common as pebbles in the sand and gravel of rivers and streams and other alluvial deposits (Bauer 1968:500). Jasper is used as an ornamental stone, especially in ancient times, although it is too abundant to be valuable and therefore needed to be polished to be used as ornamental stone, as was done in ancient times (Bauer 1968:500; Cooper 1928:50). The abundance of the stone explains why the walls of the city are of jasper ( Rv 21:18). The fact that jasper was polished as an ornamental stone explains the mention of the crystal clear jasper to which the brilliance of the New Jerusalem is compared ( Rv 21:11) (Cooper 1928:50).

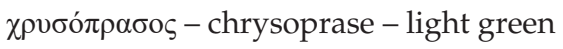

Revelation 21:20

The term $\chi \rho v \sigma o ́ \pi \rho \alpha \sigma o \varsigma$ is a hapax legomena in Koine Greek. It is translated/transliterated by the Greek dictionaries (Abbott-Smith 1937:485; Arndt \& Gingrich 1957:897; Bauer et al. 2000:465; Liddell et al. 1968:2011; Liddell \& Scott [1871] 1976:791; Montanari 2015:2388) as 'chrysoprase'. It is a loanword in English with the same referent as in Greek from Old French crisopace, via Latin (chrysopassus var. of

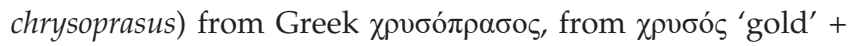

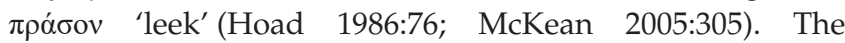
chrysoprase (Afrikaans: chrisopraas) is a light green precious stone, a variety of compact quartz, like jasper.

\section{Crystallised quartz}

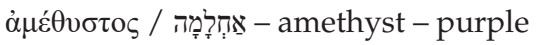

LXX Exodus 28:19, 36:19, LXX Ezekiel 28:13,

MT Exodus 28:19, 39:12

Revelation 21:20

Greek (Abbott-Smith 1937:24; Arndt \& Gingrich 1957:44; Bauer et al. 2000:52; Liddell et al. 1968:79; Liddell \& Scott [1871] 1976:39; Lust et al. 2003:32; Montanari 2015:105; Muraoka 2009:31) and Latin (Lewis \& Short [1879] 1945:105) dictionaries translate the term with amethyst. The term 'amethyst' entered into English via Old French from Latin

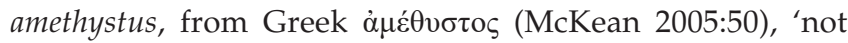
drunken' because the stone was believed to prevent intoxication (Ayto 1990:23; Hoad 1986:15-16). The term

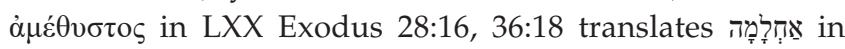
Exodus 28:19, 36:19, which is translated by Brown et al. (1979:29) with 'amethyst'. Köhler and Baumgartner (2001:34)

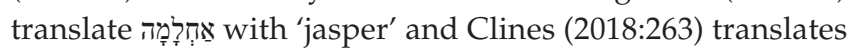
'amethyst, jasper, or similar (semi-) precious stone'. As

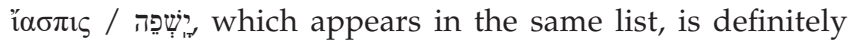
identified as 'jasper', the possibility of translating אַחְלָלָה with 'jasper', as suggested by Köhler and Baumgartner (2001:34), Clines (2018:263) and Harrel, Hoffmeier and Williams (2017:25), is excluded. Quiring (1954:206) concluded that 'amethyst' is the best translation for the Greek, Hebrew and Akkadian (algamišu) terms, which have the same referent. The term אַחְלָמָה is the word for 'amethyst' in Modern Hebrew (Alcalay 1963-1965:61). Amethyst (Afrikaans: ametis) is either a precious stone consisting of a violet or purple variety of crystallised quartz $\left(\mathrm{SiO}_{2}\right)$, the occidental amethyst or a deep purple variety of corundum $\left(\mathrm{Al}_{2} \mathrm{O}_{3}\right)$, also called the 'oriental amethyst' (Bauer 1968:294, 481-486; Gove 1966:69). The term 'oriental' is applied to the more valuable stone and 'occidental' to the less valuable stone on the basis of their quality and not their geographical origin; the terminology derives from the Middle Ages when it was believed that the stones have different geographical origins (Bauer 1968:69-70). The colour of both is very similar and the term 'amethyst' was associated with both stones for this reason (Bauer 1968:482). The first referent is the most plausible for the biblical usage.

\section{Chalcedony}

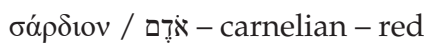

LXX Exodus 25:7, 28:17, 35:9, 36:17, LXX Ezekiel 28:13, LXX

Proverbs 25:11, 12,

MT Exodus 28:17, MT Exodus 39:10, MT Ezekiel 28:13, 
Revelation 4:3, 21:20

The Greek dictionaries translate the term as 'carnelian or sardium/sard(ius) sardian' (Abbott-Smith 1937:402; Arndt \& Gingrich 1957:750; Bauer et al. 2000:913; Liddell et al. 1968:1584; Liddell \& Scott [1871] 1976:630; Lust et al. 2003:548; Montanari 2015:1897; Muraoka 2009:617). Harrel (2011:160)

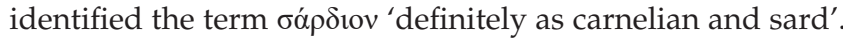
Le Boulluec and Sandevoir (2004:287) indicated that the term refers to a red stone, 'la corneline', associated with the village

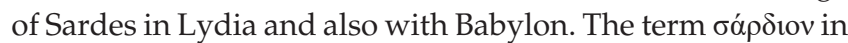
LXX Exodus 28:17 and 36:17 translates in Exodus 28:17, 39:10, which is typified in Clines (2018:153) as 'cornelian, sard or similar red (semi-)precious stone, rather than ruby', which is a shift in the interpretation from his earlier dictionaries (Clines 1993:130, 2009:5). Köhler and Baumgartner (2001:15) translated Brown et al. (1979:9) translated (1954:195-196) translated it as sard. The term i़ is the word for 'carneol' in Modern Hebrew (Alcalay 1963-1965:27). Sardius, sard, sardian stone, of which carnelian is one variety, is a loanword in Late Middle English from French sarde or Late Latin sarda via Greek (Hoad 1986:417; McKean 2005:1504-1505). In the LXX Proverbs 25:11-12 translation, the term $\sigma \alpha ́ \rho \delta$ ov is added to explicate both of the proverbs in the Masoretic Text (MT). The first Hebrew proverb describes a word fitly spoken as 'apples of gold in a setting of silver'

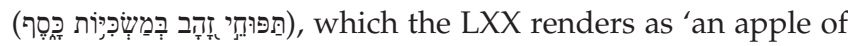

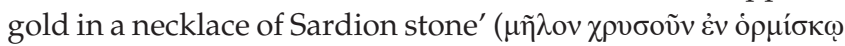

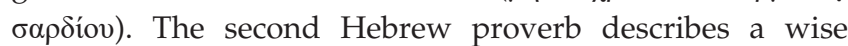
reprover to a listening ear as 'a gold ring or an ornament of

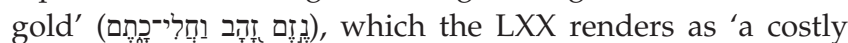

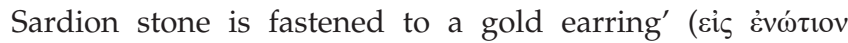

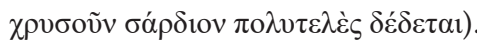

In LXX Exodus 25:7 and 35:9 the compound $\lambda \dot{\theta} \theta$ ov $\sigma \alpha \rho \delta$ íov is

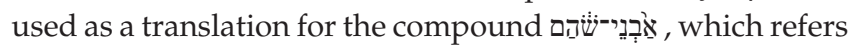
to onyx, a variety of agate (see below). In the lists in LXX Exodus 28:20, 36:12, שיהםם is associated with $\beta \eta \rho v ́ \lambda \lambda$ iov, which is beryl. In Miller-Naudé and Naudé (2020), it is shown that the Greek list reflects a different order than the Hebrew in some cases. From these usages, it can be concluded that the Greek translator(s) has difficulty in finding a translation equivalent for the Hebrew source text term. We will return below to the problematic aspects of the varieties of agate.

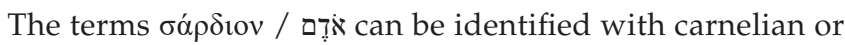
cornelian (Afrikaans: karneool), a semiprecious translucent stone, which is a red or reddish (orange or orange-red) variety of chalcedony. The stone polishes well and retains its high polish better than many harder stones; as a result it was used for seals in the ancient Near East (Gove 1966:340; Hoad 1986:98; McKean 2005:260). It is a close relative of sard, differing only in the shade of red. Compared with red jasper, which is opaque, all carnelians are translucent (Bauer 1968:508).

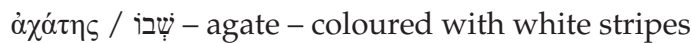

LXX Exodus 28:19, 36:19, LXX Ezekiel 28:13,
MT Exodus 28:19, 39:12

The Greek dictionaries translate the term as 'agate' (Chamberlain 2011:29; Liddell et al. 1968:295; Lust et al. 2003:99; Montanari 2015:363; Muraoka 2009:109), which is a loanword in English since the late 15th century from French,

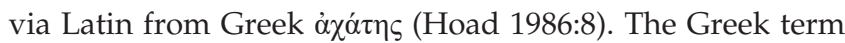
àxó $\tau$ in LXX Exodus 28:19, 36:19, LXX Ezekiel 28:13 translates שִ in MT Exodus 28:19, 39:12. The Hebrew dictionaries (Clines 2011:225; Köhler \& Baumgartner 2001) translate the term with 'agate'. The Hebrew term is a loanword from the Akkadian šubû, which refers to 'agate' (Harrell et al. 2017:23-24; Köhler \& Baumgartner 2001:1383). These terms all refer to the same stone. The term שị is the word for 'agate' in Modern Hebrew (Alcalay 1963-1965:2521). Agate (Afrikaans: agaat) is an ornamental stone consisting of a hard variety of chalcedony, typically having various colours arranged in stripes or bands (Gove 1966:40; McKean 2005:29); specifically milk-white bands alternate with bands of another colour (Bauer 1968:512). Theophrastus' high praise of agate that was followed by Pliny the Elder's low esteem of agate explains why gemstones such as agate fell out of favour in Imperial Rome when coloured transparent stones became popular (Harrell 2011:152-153). This view offers a possible explanation for why 'agate' is absent as a foundation stone in New Jerusalem (Rv 21:19-21).

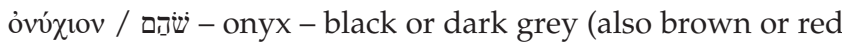
before the narrowing of meaning with the introduction of $\sigma \alpha \rho \delta$ óvv $\xi$, see below) with white stripes

LXX Exodus 28:20, 36:20, LXX Ezekiel 28:13

MT Genesis 2:12, MT Exodus 25:7, 28:20, 35:9, 27, 39:6, 13, MT

Ezekiel 28:13, MT Job 28:16, MT 1 Chronicles 29:2

The Greek term óví $\chi$ lov refers to a kind of onyx (Chamberlain 2011:121; Liddell et al. 1968:1234; Lust et al. 2003:440; Montanari 2015:1467; Muraoka 2009:499), a gem streaked with veins (Liddell \& Scott [1871] 1976:491). The Greek term became a loanword onycha in Latin and was then borrowed into Old French and Middle English (Hoad 1986:323; McKean 2005:1190). In the list of precious stones of the high priest's breastpiece in LXX Exodus 28:20, 36:12 ovvóxiov is associated

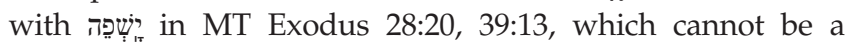
translation of above. This is an indication that the Septuagint does not follow the order of the Hebrew Bible (Miller-Naudé \& Naudé 2020). In addition and as indicated above, the lists in LXX Exodus 28:20, 36:12, שنהם is associated with $\beta \tilde{\text { in }} \rho \lambda \lambda$ os, which is beryl.

The Hebrew term in MT Exodus 28:20, 39:13 translated with

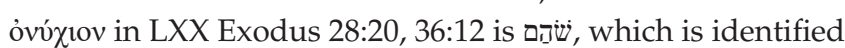
by Clines (2009:450, 2011:271) as onyx. Köhler and Baumgartner (2001:1424) suggested red carnelian, which is not possible, because red carnelian is represented by the same list. Brown et al. (1979:995) did not provide a specific identification of the term and suggested onyx, chrysoprasus, beryl and malachite as possibilities. The association with onyx is supported by LXX Job 28:16. In LXX Job 28:16 the translator(s) used the term ővv 


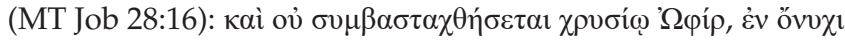

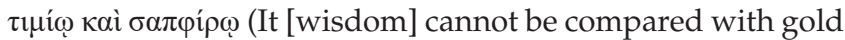

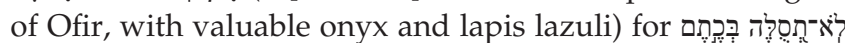

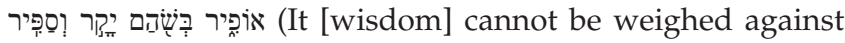
gold from Ofir, with precious onyx or lapis lazuli). The term iשהם is the word for 'onyx' in Modern Hebrew (Alcalay 19631965:2553).

Muraoka (2009:499) and Liddell et al. (1968:1234) stated that

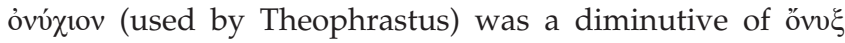
(used in Classical Greek, e.g. by Homer). The other usages of ővv $\xi$ are as follows (Chamberlain 2011:121; Hatch \& Redpath 1998/1902:1000; Lust et al. 2003:440; Muraoka 2009:499): 'shellac' (LXX Ex 30:34, Sir 24:15, see Naudé \& Miller-Naudé 2019:189-193), 'hoof/claw/talon' (LXX Lv 11:7; LXX Dt 14:8, LXX Ezk 17:3, 7, 4 Macc 9:26) and 'nails' (LXX Dan 4:31, 7:19). According to Ayto (1990:373) the resemblance to fingernails with their paler crescent-shaped mark at the base led the Greeks to name the stone ovvv . The term onyx (Afrikaans: oniks) is applied to a semi-precious variety of agate in which the second set of bands are dark grey or black (Bauer 1968:512). According to Harrell (2011:158), onyx was used for cameo relief carvings during the Hellenistic and Roman periods with the result that this hugely popular gemstone would have been distinguished from agate (Harrell 2011:158).

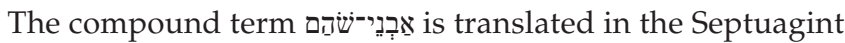
with other terms by the various translators of each book. In 1 Chronicles 29:2 it is transliterated as $\lambda i \theta$ oi $\sigma 00 \mu$ by the translator(s) of 1 Chronicles (Chamberlain 2011:152; Taylor 2009:497) in a list of precious materials collected for the building of the temple. In the LXX of Genesis 2:12 the

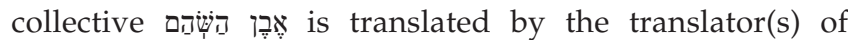
Genesis as ó $\lambda i ́ \theta$ os ó $\pi \rho \alpha ́ \sigma ı v o \varsigma$. As indicated here, in LXX Exodus 25:6 and 39:9 the compound $\lambda i \theta$ ov $\sigma \alpha \rho \delta i$ ov is used by the translator(s) of Exodus as translation for the

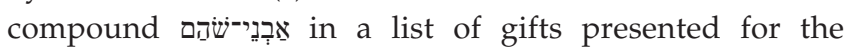
tabernacle and priestly garments. In LXX Exodus 35:27 and

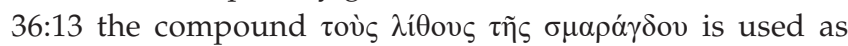

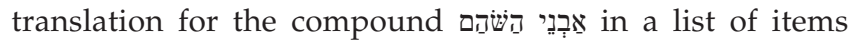
brought for constructing the ephod and breastpiece. From these usages, it can be concluded that the Greek translator(s) had trouble finding a translation equivalent for the Hebrew source text term.

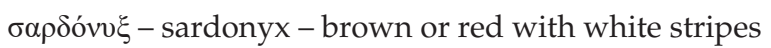

Revelation 21:20

The term $\sigma \alpha \rho \delta$ óvv $\xi$ is translated in the Greek dictionaries (Abbott-Smith 1937:402; Arndt \& Gingrich 1957:750; Bauer et al. 2000:913; Liddell et al. 1968:1584; Liddell \& Scott [1871] 1976:630; Montanari 2015:1897) as sardonyx, a stone marked by the red of the sard and the white of the onyx as shown by the etymology of the word: Middle English < Latin sardonyx < Greek $\sigma \alpha \rho \delta$ óvv $\xi$, probably from $\sigma \alpha \rho \delta 10 \varsigma$ 'sardius' + övv $\xi$ 'onyx' (Hoad 1986:417; McKean 2005:1505). According to Harrell (2011:158-159) it is only in the Imperial Roman period that a distinction was made between onyx and sardonyx, with Pliny the Elder's account being the earliest. It replaced the term óvó $\chi 10 v$ in the list of foundation stones in Revelation 21:20. The term sardonyx (Afrikaans: sardoniks) refers to a semi-precious variety of agate, a kind of onyx in which the second set of bands are brown or red (Harrell 2011:158).

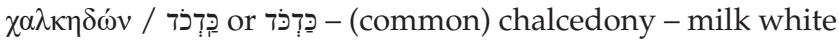
MT Isaiah 54:12, MT Ezekiel 27:16,

Revelation 21:19

The term $\chi \alpha \lambda \kappa \eta \delta \omega v$ is translated in the Greek dictionaries (Abbott-Smith 1937:478; Arndt \& Gingrich 1957:882; Bauer et al. 2000:1076; Liddell et al. 1968:1973; Liddell \& Scott [1871] 1976:776; Montanari 2015:2334) as chalcedony.

The English term chalcedony is a loanword from the 15th to the 16th century via the Latin term $c(h) a l c e d o n i u s$ from Koine Greek ( $R v$ 21:19) (Hoad 1986:69, McKean 2005:281). It is assumed to mean 'stone of Chalcedon' in Asia Minor, but variant Latin forms $\operatorname{carc}(h)$ edonia, -ius led to the association with Carthage (Greek Karkhedon) (Hoad 1986:69; McKean 2005:281). The term chalcedony either refers to a specific stone, common chalcedony or to the group to which carnelian, agate, onyx, sardonyx and common chalcedony belong (Bauer 1968:506-508, see also Noonan 2019:115-117). Bauer (1968:506) described common chalcedony as similar to agate. It is structured in layers, but all layers are of the same colour, rendering the banded structure inconspicuous. If the bands are prominent, the stone is referred to as agate.

A possible Hebrew term for common chalcedony is

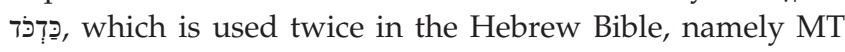
Ezekiel 27:16 and MT Isaiah 54:12. In LXX Ezekiel 27:16, the translator(s) lacked both knowledge of the Hebrew terms for the precious stones and other commerce (in an incipient unvocalised text) as well as appropriate Greek terms that

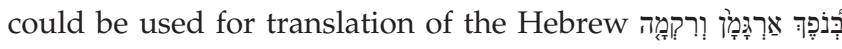

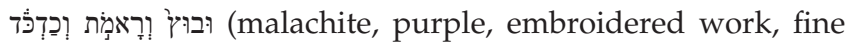
linen, pearls and chalcedony). The translation strategy followed by the translator(s) of LXX Ezekiel 27:16 is to use a substitution strategy based on etymology to replace the goods with commerce that was known and to connect them to the place name where the commerce originated: $\sigma \tau \alpha \kappa \tau \eta े \nu$

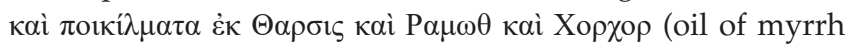
and brocades from Tharsis and Ramoth and Chorchor).

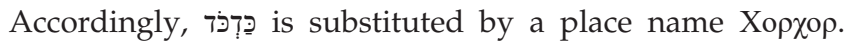
Similarly, by lack of identification of the stone, the translator(s) of the Vulgate transliterated the Hebrew term into Latin as chodchod.

Brown et al. (1979:461) and Köhler and Baumgartner (2001:460) proposed an identification for According to Harrell et al. (2017:32) ruby was firstly unknown in the Near East prior to the 1st century CE and secondly ruby is too small, rare and precious to have been

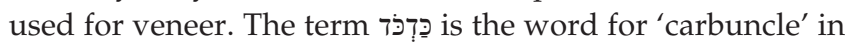
Modern Hebrew (Alcalay 1963-1965:995). According to Ayto (1990:97) the term comes from Latin carbunculus, which is late and not relevant for identification in this regard. 
Furthermore, in the Vulgate carbunculus is used to translate the stone described as $\alpha v \theta \rho \alpha \xi$ in the LXX and ip in the MT. Harrell et al. (2017:32-33) considered gypsum plaster as a possible identification, but suggested in the end reddish limestone as the identification of כִָּ This is unlikely because both gypsum and limestone are soft and very difficult to facet. Nowhere is there an identification of gypsum and limestone as precious stones nor are they mentioned together with precious stones. Clines (1998:362, 2009:172) proposed agate, which is within the group of chalcedony stones, but is excluded because of its structure as discussed above and the fact that there is a Hebrew term associated with agate, namely שֶׁ. Because a Greek term was lacking at the time when the translation was completed, the translator(s) of LXX Isaiah 54:12 used i $\alpha \sigma \pi ı$ to translate

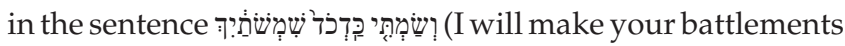
of chalcedony). As indicated above, jasper is abundant in the Near East and is the best choice to veneer the battlements

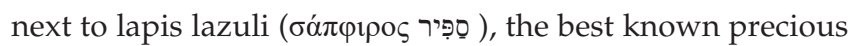
stone in the Near East, which is consistently translated in the Septuagint with the same term (see below) and would not fit

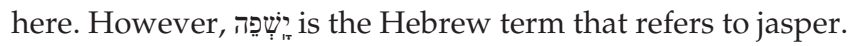
If it is assumed that is is common chalcedony, a milk white microcrystalline variety of chalcedony, and as quartz looks very similar to jasper, these features explain this choice by the translator(s). Given this circumstantial evidence, it seems that the best identification of $\chi \alpha \lambda \kappa \eta \delta \omega \dot{v}$ and with chalcedony. The term common chalcedony (Afrikaans: chalcedoon) refers to a milk white microcrystalline variety of chalcedony.

\section{Lazurite}

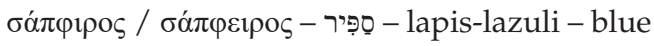

MT Exodus 24:10, 28:18, 39:11, MT Isaiah 54:11, MT Ezekiel 1:26, 9:2, 10:1, 28:13, MT Job 28:6, 28:16, MT Song of Songs 5:14, MT Lamentations 4:7.

LXX Exodus 24:10, 28:18, 36:18, LXX Isaiah 54:11, LXX Ezekiel 1:26, 9:2, 10:1, 28:13, LXX Job 28:6, 28:16, LXX Canticles 5:14, LXX Lamentations 4:7, LXX Tobit 13:17.

Revelation 21:19.

The Greek and Hebrew dictionaries differ in the referent of the term. For Lust et al. (2003:548) it is sapphire. For AbbottSmith (1937:402) and Brown et al. (1979:705) it is also sapphire, but they indicate that it may be perhaps lapis lazuli. Arndt and Gingrich (1957:749), Liddell and Scott ([1871] 1976:630), Bauer et al. (2000:913) and Montanari (2015:1897) provided both lapis lazuli and sapphire as referents. For Liddell et al. (1968:1583), Muraoka (2009:617), Clines (2009:301) and Köhler and Baumgartner (2001:764) it is lapis lazuli. Clines (2007:181) specifically excludes sapphire as a possibility and states that the referent is lapis lazuli. Lisowsky ([1958]1993:1003) gave the meaning as lapis lazuli. All usages of the Hebrew term are translated as

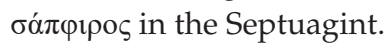

The English term sapphire can be traced back through Old French safir and Latin sapphírus to Greek $\sigma \alpha \pi \varphi$ ípos and
סַפִּיר (Ayto 1990:456). Gove (1966:2013) and Hoad (1986:258) indicated the Sanskrit term śanipriya as its origin. However, the English term, on the one hand, and the Greek and Hebrew terms, on the other hand, are false friends (Crystal 1997:349). As mentioned above, the term sapphire (Afrikaans: saffier) refers in modern languages to a transparent precious stone, typically blue, which is a variety of corundum (aluminium oxide), but in Biblical Hebrew and Biblical Greek it denotes lapis lazuli (Afrikaans: lasuursteen), also a blue stone but consisting largely of lazurite (Bauer 1968:438; Gove 1966:1271; Hoad 1986:246, 417; McKean 2005:902, 953, 1504). Similarly, the term 'sapphire and lapis lazuli' in Modern Hebrew (Alcalay 1963-1965:1805). According to Gove (1966:1271) lapis lazuli is loaned via Middle Latin from Arabic and thus has a late origin. Bauer (1968:438-439) described lapis lazuli (azure stone, oriental lapis-lazuli) as 'an opaque mineral (a rock that consists of lazurite, calcite and pyrite), usually of a magnificent colour', which is not a homogeneous mineral, like quartz, but a mixture of minerals that consist of various chemicals (silica, alumina, ferrie oxide, lime, soda, sulphuric anhydride and sulphur) but not in the same proportion. The colour is far more intense and beautiful than any other opaque blue stone (Bauer 1968:438), and this provides the reason for transplanting the term to the blue corundum, when it was discovered in later times. Lapis lazuli is used for gems and small articles cut out of a single piece of material, as well as for mosaics, inlaying and veneering with thin plates of lapis lazuli (Bauer 1968:445). A modern example is the Winter Palace at St. Petersburg, in which there are rooms that are wainscoted with lapis lazuli (Bauer 1968:445). These usages of lapis lazuli fit into the usages as depicted in the various biblical texts. In MT Exodus 28:18, 39:11, MT Ezekiel 28:13 and LXX Exodus 28:18, 36:18, LXX Ezekiel 28:13, the term refers to a gem on the breastpiece of Aaron, and on the covering the king of Tyrus. In MT Song of Songs 5:14, LXX Canticles 5:14 it refers to gems as adorning the arms of the beloved.

In MT Exodus 24:10, LXX Exodus 24:10, MT Isaiah 54:11, LXX Isaiah 54:11, MT Ezekiel 1:10, 26, LXX Ezekiel 1:10, 26, LXX Tobit 13:17, Revelation 21:19 it refers to stones or tiles, which can be used for pavement and foundations. In MT Job 28:6, 28:16, MT Lamentations 4:7, LXX Job 28:6, 28:16, LXX Lamentations $4: 7$ the term refers to the beauty of lapis lazuli as a precious stone.

The translator(s) of LXX Ezekiel 9:2 interpreted and translated the (unvocalised) Hebrew term הספֵפ in MT Ezekiel 9:2 as the precious stone бó $\pi$ фipos. The MT describes six men each of

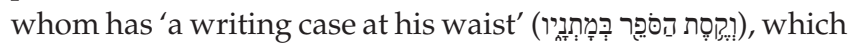
the LXX renders as 'and a sapphire belt was upon his loin'

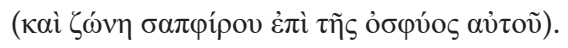

\section{Topaz}

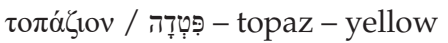

MT Exodus 28:17, 39:10, MT Ezekiel 28:13, MT Job 28:19 
LXX Exodus 28:17, 36:17, LXX Ezekiel 28:13, LXX Job 28:19, LXX Psalm 118:127

Revelation 21:20

The fact that all cases of פִִּ in the Hebrew Bible (MT Ex 28:17, 39:10, MT Ezk 28:13, MT Job 28:19) are translated by

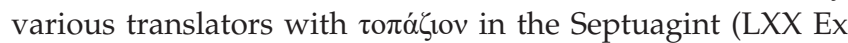
28:17, 36:17, LXX Ezk 28:13, LXX Job 28:19) indicates that the identification of this precious stone in the incipient texts and subsequent texts was familiar to them.

In cases where a specific term is lacking in the subsequent language there is variation in the terms used by the translators, because they apply a translation strategy of cultural substitution that involves replacing a culturespecific item with a term that does not have the same propositional meaning, but is likely to have a similar impact on the target reader (Van Rooyen \& Naudé 2009:258). For example, as confirmed by the cases discussed here, Greek lacks a term to translate

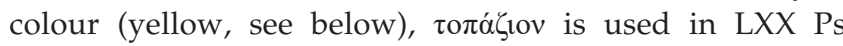

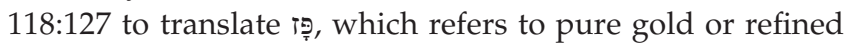

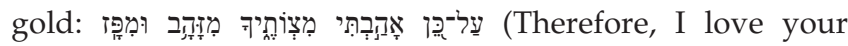

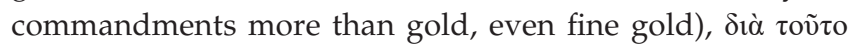

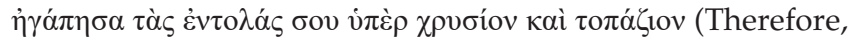
I loved your commandments beyond gold and topaz). The lack of a Greek term for is is confirmed by the translation of the term in MT Psalm 19:11, 21:3, MT Isaiah 13:12, MT Proverbs 8:19, MT Song of Songs 5:11, 15, 4:2 either with a

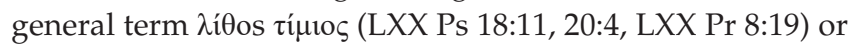
a term with a related meaning $\chi \rho v \sigma i ́ o v$ (LXX Is 13:12, LXX Can 5:11, 15, 4:2).

From the above-mentioned consistent usage of the terms by the various translators, it is possible to conclude that the translators are aware of the specific referent of

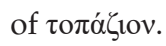

The modern term in English is a loanword via Old French

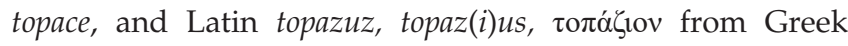
(Hoad 1986:498; McKean 2005:1777).

Most Greek dictionaries (Abbott-Smith 1937:448; Arndt \& Gingrich 1957:829-830; Bauer et al. 2000:1010; Liddell \& Scott [1871] 1976:710; Lust et al. 2003:617; Montanari 2015:2133;

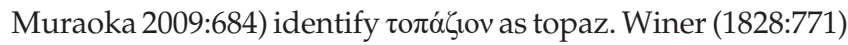
and the predecessors of Brown et al. (1979) (namely, Gesenius 1847:749; Múhlau \& Volck 1878:684; Robinson 1871:842; Tregelles [1857] 1950:672) identified described it as a pale yellowish gem found on an island in the Red Sea based on Pliny's identification. The origin of the word is sought in Sanskrit where pita is yellowish, pale and that the Greek name itself might originate by metathesis/transposition

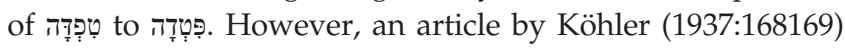
brought a reinterpretation, which seems to be a wrong turn. The claim by Köhler (1937:168-169) is based on a combination of (1) the evidence of MT Job 28:19, which mentioned פּ כ as the place of origin of Pliny the Elder (23/4-79 CE) in Naturalis Historia Book xxxvii
(Mineralogy and Metallurgy and their use in the arts), which mentioned the location as an island in the Red Sea to be identified with the term topaz, and (3) the geological/ mineralogy and geographical information in the 1932 German edition of Bauer (1968), which is an English translation of the 1903 German edition. According to the last-mentioned source (Bauer 1932), the specific location (Jazīrat Zabarjad [Saint Johns Island]), which is a source of chrysolite, was discovered in 1900 and led Köhler together with the information in Job and Philo to conclude that the mineral under discussion is not topaz but chrysolite. For the first two editions of Köhler and Baumgartner $(1953,1958)$ 'chrysolite' was therefore the choice based on Köhler (1937:168-169). This rendering probably influenced various dictionaries, for example Brown et al. (1979), where there is a shift from its predecessors and the term is now identified as either topaz or chrysolite, as well as

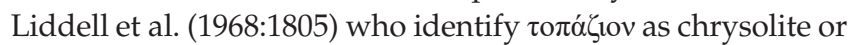
peridot. Similarly, Clines (2007:679) identified פְְִּ as a 'translucent pale green gem form of olivine, an iron magnesium silicate, formerly known as chrysolite (often incorrectly "topaz")' and Clines (2009:356) as 'peridot, Peridot of Ethiopia' (Job 28:19). Even the description of topaz in Encyclopaedia Britannica (2006) demonstrates the view:

[T] hat the topaz of modern mineralogists was unknown to the ancients and that the stone called topazos was the mineral chrysolite or peridot. The 'topaz' in the Old Testament also may have been chrysolite. (n.p.)

This statement of a shift in the referent is at least not true for the Hebrew Bible and the Septuagint in the light of the following considerations.

Köhler and Baumgartner (1967:873, 2001:924) identified it with topaz with the specification that this is in contrast to earlier editions of Köhler and Baumgartner (1953, 1958), which implies a rejection of Köhler (1937:168-169). Based on Quiring (1954:196-197), who also rejected Köhler (1937:168169), Zimmerli ([1969]1979:673) supported an identification of the Hebrew Bible, Septuagint and Vulgate terms with topaz and recognised that the shift towards chrysolite as referent was because of Pliny, which is late (70 CE). The term is the word for 'topaz' in Modern Hebrew (Alcalay 19631965:2026). According to Bauer (1968:339-340), yellow topaz is found in Asia Minor and Ancient Egypt. In Egypt numerous ancient topaz mines have been discovered.

Further support comes from the fact that the terms topaz and chrysolite both occur together in each Hebrew, Greek and Latin list as separate terms; this collocation has not received adequate attention in previous research. If yellow topaz refers to chrysolite, the problem is then the identification of the referent of chrysolite.

Given this evidence, it is assumed that the referent of at least the Hebrew and Greek terms in the Bible is the same as modern topaz. The term topaz (Afrikaans: topaas) refers to an aluminium silicate mineral containing fluorine $\left(\mathrm{Al}_{2} \mathrm{SiO}_{4}(\mathrm{~F}, \mathrm{OH})_{2}\right)$ that is valued as a yellow gemstone. 


\section{Olivine}

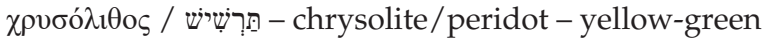
MT Exodus 28:20, 39:13 MT Ezekiel 1:16, 10:9, 28:13, MT Song of Songs 5:14, MT Daniel 10:6

LXX Exodus 28:20, 36:20, LXX Ezekiel 28:13

Revelation 21:20

The term תַּר in in MT Exodus 28:20, 39:13, MT Ezekiel 28:13 is translated with $\chi \rho v \sigma o ́ \lambda \imath \theta o \varsigma$ in LXX Exodus 28:20, 36:20, LXX Ezekiel 28:13. However, in LXX Ezekiel 1:16, LXX Daniel 10:6 and LXX Canticles 5:14 the term sị

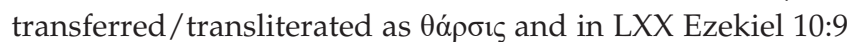

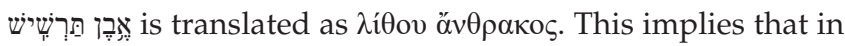

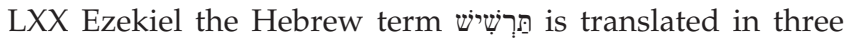
different ways. The list in LXX Ezekiel 28:13 is normalised to be equal to the earlier LXX Exodus lists. From this one can conclude that the later LXX translators did not know the referent of the Hebrew term any more, which the translator(s) of LXX Exodus knew.

It was shown in the previous section that topaz as used in the Bible is (wrongly) associated with chrysolite by Köhler (1937:168-169). It is then not strange that some dictionaries associated the term $\chi \rho v \sigma o ́ \lambda ı 0 s$ with topaz, for example 'yellow topaz' (Muraoka 2009:738) and 'topaz' (Liddell et al. 1968:2010). Liddell and Scott ([1871] 1976:791) suggested 'chrysolith or gold-stone, a bright yellow stone, perhaps the topaz'. Bauer et al. (2000:1093) had a similar suggestion. The other Greek dictionaries (Abbott-Smith 1937:485; Arndt \& Gingrich 1957:896-897; Lust et al. 2003:669; Montanari 2015:2387) associate the Greek term with chrysolite or peridot in the Septuagint, New Testament and Classical Greek.

The identification of תַּ with jasper by Brown et al. (1979:1797) is not possible, because there is a specific Hebrew term for jasper as shown above and both Hebrew terms occur in the same list. The same pertains to the identification of the term sִ with beryl (see below) and topaz in the following dictionaries. Köhler and Baumgartner (2001:1797-1798) identified it as a precious stone, probably (Spanish) topaz. Clines (2009:495, 2011:680) had 'topaz or perhaps beryl or chrysolite' as possibilities. The term תֵา is used for 'topaz, beryl and chrysolite' in Modern Hebrew (Alcalay 1963-1965:2026).

The English term chrysolite is loaned from Old French crisolite, via medieval Latin crisolitus, Latin chrysolithus,

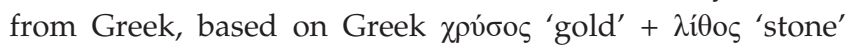
(Hoad 1986:76; McKean 2005:305). This term has become less common for the gemstone and is replaced by peridot. Peridot (chrysolite, Afrikaans: chrisoliet), a magnesium iron silicate $(\mathrm{MgFe})_{2} \mathrm{SiO}_{4}$, is a yellowish-green variety of olivine, used as a gemstone.

\section{Beryl}

The mineral species beryl is a silicate of the metals aluminium and beryllium. The different varieties of beryl include aquamarine, emerald and common beryl. They have identical features and differ only in colour (Bauer 1968:306).

יִדְלם (Bomberg) - aquamarine - turquoise MT Exodus 28:18, 39:11, MT Ezekiel 28:13

The term ינדים is the word for 'diamond' in Modern Hebrew (Alcalay 1963-1965:912). However, diamonds were unknown in the Near East prior to the Roman period and can therefore not be related to the term in the Hebrew Bible (Platt 2007:120). The Biblical Hebrew term שִָׁ (Jr 17:1, Ezk 3:9 and Zch 7:12) that is translated as 'diamond' in most Bible translations refers to flintstone (Brown et al. 1979:1038).

Köhler and Baumgartner (2001:397) provided a general term 'precious stone' to translate the culture-specific Hebrew term and state that the etymology and meaning are uncertain. Brown et al. (1979:240) suggested the same strategy but provided jasper or onyx as other possibilities to consider. Clines (1998:159, 2009:149) proposed onyx. As í $\alpha \sigma \pi \varsigma$ / and óvóxiov / שה that appear in the same list are definitely identified as 'jasper' and 'onyx', respectively, the possibility

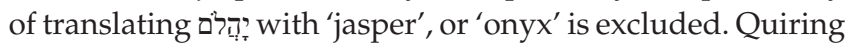
(1954:118) suggested 'moonstone' on the assumption of an Akkadian gemstone hulālu, but linguistically it is problematic to derive יָָָּלם etymologically from the Akkadian term. Accordingly, on the ground of the similarity of colour of moonstone, Harrel, Hoffmeier and Williams (2017:20-22) suggested 'either milky quartz or sapphirine chalcedony'.

In the Peshitta, the sixth stone, $n q$ ' $t$ ', which is the translation

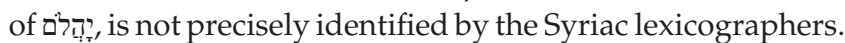
Sokoloff defines it as 'gem, perhaps topaz' and suggests that the term may be derived by metathesis from ענקתא 'necklace' (Sokoloff 2009:947). Payne Smith defines it only as a darkcoloured or honey-coloured gem (Payne Smith 1903:351).

In sixth position, the Targumim has three different terms as

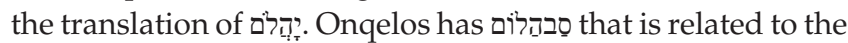

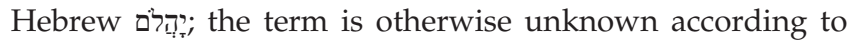
Jastrow (1967:949). Pseudo-Jonathan has כדכודין, one of the alternate terms for 'chalcedony' (see Sokoloff 2002:251). Neofiti has עין־עגלה, literally 'calf's eye', a metaphorical term for a precious stone (Sokoloff 2002:403).

The stones in the two Exodus lists in the Vulgate are in identical order and follow the Septuagint, except in the reversal of berillus and onycinus. This reversal means that the Vulgate onychinus correlates correctly with the Hebrew שה שים (onyx). However, the Vulgate correlation of iaspis with the LXX i $\alpha \sigma \pi ı$ should not be correlated with the Hebrew יִּנהלם Furthermore, the Vulgate berillus should not be correlated

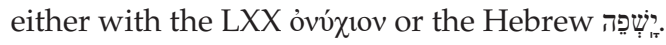

In the case of the Septuagint translator(s) rendered it with $\beta \eta \rho v i \lambda \lambda$ iov (beryl). According to Harrell (2011:154-155) the term $\beta \eta \rho v ́ \lambda \lambda 10 v$ is almost certainly aquamarine as aquamarine was in use during the late Hellenistic period and would have been one of the gemstones imported into the 
Mediterranean region from India. In the light of the different varieties of beryl - namely, aquamarine, emerald and common beryl, for each of which there is a possible Hebrew term - our view is that in the case of ידידה the Septuagint translator(s) rendered it with the closest equivalent known to him, namely $\beta \eta \rho v i \lambda$ 1ov (beryl), a blue-green stone in the same mineral family as the aquamarine. However, the referent of יָדיהלם is aquamarine, a stone in the beryl family that is turquoise in colour. The Septuagint translator(s) does not have a term

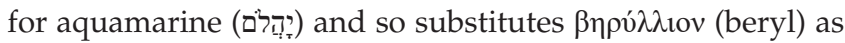
his rendering.

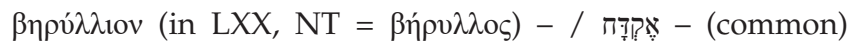
beryl - blue green

MT Isaiah 54:12

LXX Exodus 28:20, 36:13, LXX Ezekiel 28:13, LXX Tobit 13:17 Revelation 21:20

Theophrastus does not mention $\beta \eta \rho v ́ \lambda \lambda$ ıov. Pliny the Elder described $\beta \eta \rho v ́ \lambda \lambda$ iov as analogous to $\sigma \mu \alpha \dot{\alpha} \rho \alpha \gamma \delta \delta_{\text {, having a }}$ hexagonal shape and the pure green of the sea (Bostock \& Riley 1857:414-415). As was indicated in the previous section,

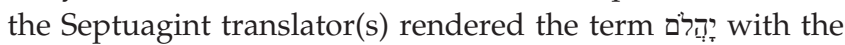
closest equivalent known to him, namely $\beta \eta \rho v i \lambda \lambda_{10 v}$ in the lists in LXX Exodus 28:20, 36:13 and LXX Ezekiel 28:13. It is

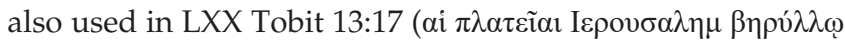

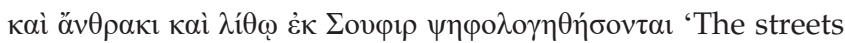
of Jerusalem will be paved with beryl and malachite and stones of Ophir'). The Greek dictionaries (Abbott-Smith 1937:81; Arndt \& Gingrich 1957:140; Bauer et al. 2000:175; Liddell et al. 1968:314; Liddell \& Scott [1871] 1976:129; Lust et al. 2003:107; Montanari 2015:385; Muraoka 2009:117) suggested 'beryl' as the translation for $\beta \eta \rho v ́ \lambda \lambda$ เov / $\beta \eta \rho v ́ \lambda \lambda$ os.

Lisowsky ([1958]1993:136) suggested beryl as the identification of אֶקָ Similarly, Köhler and Baumgartner (2001:82) suggested

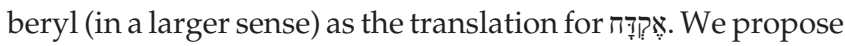

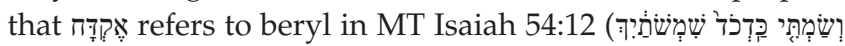

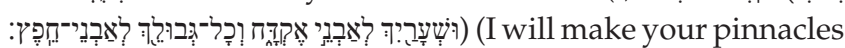
of chalcedony your gates of beryl, and all your wall of

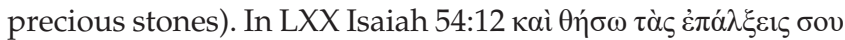

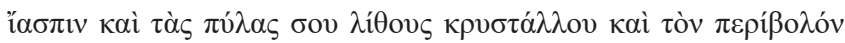

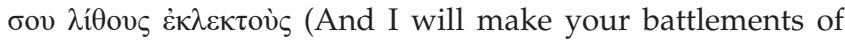
jasper and your gates of crystal stones and your enclosure of precious stones). In the absence of a Greek term to translate

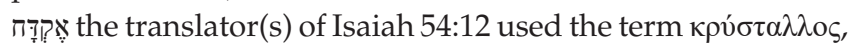
which refers to a very hard, translucent and usually transparent type of quartz (Bauer 1968:474-479; Louw \& Nida 1988:26); this was the nearest Greek term resembling beryl. Common beryl usually occurs as crystals in coarsegrained granite and was known in the Ancient Near East (Bauer 1968:307). Clines (2009:30, 2018:536) suggested 'perhaps beryl or red granite'. The justification of 'red granite' as translation for is not clear. The suggestion of Brown et al. (1979:869) is to translate and not relevant for identification in this regard. Furthermore, in the Vulgate the term carbunculus is used to translate ö $v \theta \rho \alpha \xi$ and נִּנִ
The term beryl is borrowed from Old French beril, via Latin beryllus from the Greek (Hoad 1986:39; McKean 2005:156). The Greek term is borrowed via Prakit veruliya from Pali veluriya (Pickett 2002:134). The term (common) beryl (Afrikaans: berilsteen) refers to a transparent blue green mineral of great hardness consisting of a silicate of beryllium and aluminum, which occurs in hexagonal prisms and is sometimes used as a gemstone.

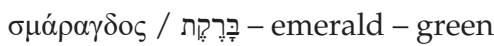

LXX Exodus 28:9, 28:17, 35:13, 35:27, 36:13, 36:17, LXX Tobit 13:16, LXX Judith 10:21, LXX Esther 1:6, LXX Sirach 35:6, LXX Ezekiel 28:13,

MT Exodus 28:17, 39:10, MT Ezekiel 28:13

Revelation 21:19

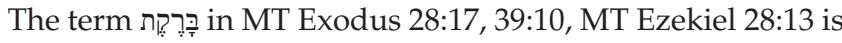
translated in LXX Exodus 28:17, 36:17 as $\sigma \mu \alpha \dot{\alpha} \rho \alpha \gamma \delta$ os. Liddell and Scott ([1871] 1976:642) had the view that it is 'a precious stone of green colour: probably not the emerald'. However, the Greek dictionaries (Arndt \& Gingrich 1957:411; Bauer et al. 2000:933; Liddell et al. 1968:1619; Lust et al. 2003:560; Montanari 2015:1938; Muraoka 2009:628) translate $\sigma \mu \alpha ́ \alpha \alpha \gamma \delta o \varsigma$ as emerald. Le Boulluec and Sandevoir (2004:355) identified

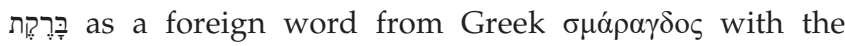
last three letters of the Hebrew word (rqt) related to the letters $r g d$ of the Greek. Noonan (2019:327-328), however,

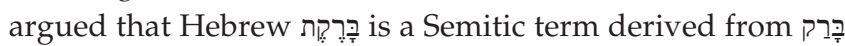
'flash, shine'. The Hebrew dictionaries (Brown et al. 1979:140; Clines 1995:275, 2009:57) translated as emerald, or precious green stone. Lisowsky ([1958]1993:289) suggested dark green beryl, which is emerald. In addition to emerald, Köhler and Baumgartner (2001:162) also suggested beryl as a possible translation. As argued above beryl is to be associated with

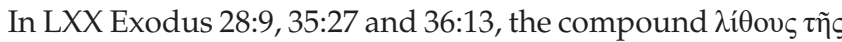

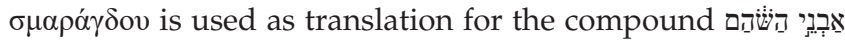
(MT Ex 28:9, 35:27, 39:6) in a list of items brought for constructing the ephod and breastpiece. It was argued above that the Greek translator(s) had trouble finding a translation

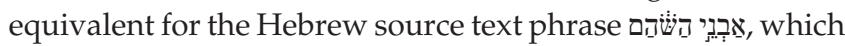
is 'stones of onyx' and therefore substituted another term referring to a precious stone.

In the ancient world, emeralds were obtained from Upper Egypt as early as 2000 BCE. Greek miners were working in the mines at the time of Alexander the Great, and later the miners yielded their gems to Cleopatra. The remains of extensive mines were discovered about 1817; 'Cleopatra's Mines' are situated in Jabal Sukayt and Jabal Zabārah near the Red Sea coast, east of Aswān ['Emerald'. Encyclopædia Britannica].

The term emerald (Afrikaans: smarag) is a bright green precious stone consisting of a chromium-rich variety of beryl that is valued as a gemstone. The term emerald (Middle English emeraude) was loaned from Old French e(s)meraude

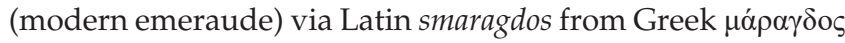


'green gem', which was superseded by a variant $\sigma \mu \alpha$ ó $\alpha \gamma \delta$ o $\varsigma$ via Prakit maragda (India was a main source of emeralds) from Semitic (bāraqt - 'gem' from bāraq - 'shine', compare

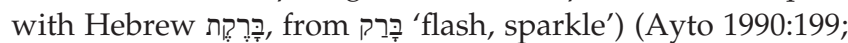
Gove 1966:741; Hoad 1986:146; McKean 2005:552).

\section{Zircon}

Zircon is a compound silicate mineral, namely zirconium silicate $\left(\mathrm{ZrSiO}_{4}\right)$ (Bauer 1968:340). Various names are applied to different colours of zircons. The transparent red, orange or yellow variety is distinguished by the name hyacinth (jacinth), the only variety used as a gem (Bauer 1968:340).

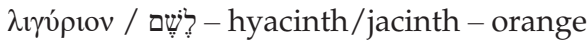

MT Exodus 28:19, 39:12

LXX Exodus 28:19, 36:19, LXX Ezekiel 28:13

The translator(s) of LXX Exodus translated לֶׁ? with $\lambda$ irvipıv in the breastpiece of the high priest (LXX-Ex 18:19, 36:19) and in the covering of the king of Tyre (LXX-Ezk 28:13). If compared with MT Ezekiel 28:13, which lacks a source text item, the translator(s) of LXX Ezekiel 28:13 added $\lambda$ ıvúpıv on account of the lists in LXX Exodus 28:19, 36:19. Köhler and Baumgartner (2001:537) and Brown et al. (1979:546) agreed

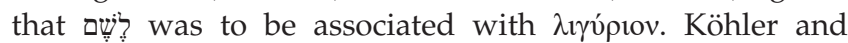
Baumgartner (2001:537) suggested various possibilities, namely a gem-stone, carnelian, hyacinth, reddish yellow amber or whitish blue feldspar. Brown et al. (1979:546) suggested a general term, namely a precious stone and they mention some other proposals in the literature, namely carbuncle, amber and jacinth. Clines (1998:580, 2009:198) translated with 'jacinth, or perhaps pale carnelian'. The Greek dictionaries transferred/transliterated or used a general term, namely ligurium (Montanari 2015:1239), stone of Liguria (Lust et al. 2003:372) and a precious stone (Liddell et al. 1968:1048; Muraoka 2009:431). In their translation of $\lambda$ เvópıov, Le Boulluec and Sandevoir (2004:287) used 'pierre de Ligurie' (stone of Ligurie) with an extensive note naming the possibilities, opal, amber, aquamarine and hyacinth. The loanword ligure is explained by Pickett (2002:802) as a precious stone of ancient Israel via Late Latin ligūrius from Greek $\lambda$ ıvópıov, the diminutive form of $\lambda$ ivópıs. According to Gove (1966:1310) the precious stone was probably the jacinth. The Greek dictionary of Chamberlain (2011:106) provides 'jacinth' as the translation. The Greek term $\lambda$ irv́pıov does not occur in the list of foundation stones of Revelation 21:19-20, but a new term is introduced, namely vóxкıv $\theta$ os, which will be discussed in the next section.

The possibility of identification with carnelian is ruled out, because carnelian is associated with Greek oóp $\delta$ เov/Hebrew אָּ, which occurs in the same list. It is already indicated that carbuncle is not possible because it is late (Ayto 1990:97). It is

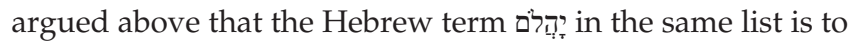
be identified as aquamarine. The Biblical Hebrew term,

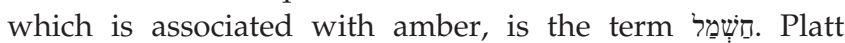
(2006:129) indicated that amber as a plant product has been found in many archaeological excavations in the Levant and was primarily used as a fragrance, a charm and a medicine, which rules the suggestion of 'amber' as a precious stone in a list of precious stones out. According to Bauer (1968:424), feldspar is cloudy, opaque and dull in colour, so that feldspar possesses none of the characteristics that would lead to its application as a gemstone or even as an ornamental stone, which rules out feldspar as a possibility. Le Boulluec and Sandevoir (2004:287) claimed that the Hebrew name of the stone is usually rendered by opal in French. Alcalay (19631965:1149) suggested 'opal (precious stone), jacinth' for לֶֶֶׁ in Modern Hebrew, but the Biblical Hebrew dictionaries (Brown et al. 1979:546; Clines 1998:580, 2009:198; Köhler \& Baumgartner 2001:537) do not offer the option of opal.

vókıv $\theta$ os - hyacinth/jacinth - orange

Revelation 21:20

The Greek dictionaries propose various translations. Liddell et al. (1968:1840) suggested a precious stone of blue colour, perhaps aquamarine. Abbott-Smith (1937:453) and Muraoka (2009:692) suggested sapphire. Liddell and Scott ([1871] 1976:723) had jacinth or perhaps the sapphire, a precious stone of blue colour as possibilities. Arndt and Gingrich (1957:839), Bauer et al. (2000:1022) and Montanari (2015:2175) translated vókıv $\theta$ os as yacinth. The term in English is a loanword from French hyacinthe via Latin hyacinthus from Greek (Hoad 1986:223; McKean 2005:829). The term vóxкıvӨos denoted a plant with red flowers, which according to legend sprang from the blood of Hyacinthus, a beautiful youth whom Apollo loved but accidently killed (Ayto 1990:290). In English it had been adopted for the bluebell, which explains that the term is sometimes associated with a deep blue colour, a modern association.

The term hyacinth/jacinth (Afrikaans: hiasintsteen) refers to a transparent orange variety of zircon used as a gemstone.

\section{Malachite}

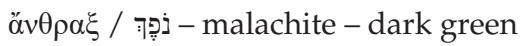

MT Exodus 28:18, 39:11, MT Ezekiel 27:16, 28:13

LXX Exodus 28:18, 36:18, LXX Ezekiel 10:9, 28:13, LXX Isaiah

54:11, LXX Genesis 2:12

The term כִכ occurs only four times in the Hebrew Bible. In three cases, namely MT Exodus 28:18, 39:11 (the breastpiece of the high priest), MT Ezekiel 28:13 (as the covering of the king of Tyre), it is translated as ö $v \theta \rho \alpha \xi$ (LXX Ex 28:18, 36:18, LXX Ezk 28:13). As was dicussed above, concerning the fourth case, LXX Ezekiel 27:16, the translator(s) lacked both knowledge of the Hebrew terms for the precious stones and other commerce (in an incipient unvocalised text) as well as appropriate Greek terms for translation of the Hebrew

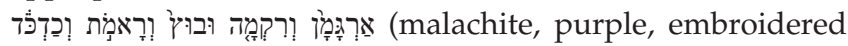
work, fine linen, pearls and chalcedony). The translator(s) of LXX Ezekiel 27:16 used a substitution strategy based on etymology to replace the goods with commerce that was known and to connect the terms to place names where the

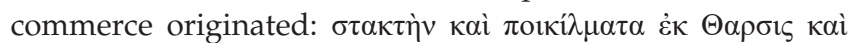

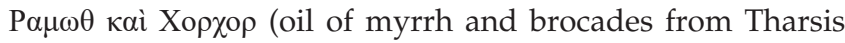
and Ramoth and Chorchor). In the list of the foundation stones of New Jerusalem ( $\operatorname{Rv} 21: 19-20)$ o $v \theta \rho \alpha \xi$ is substituted 
by $\chi \rho v \sigma o ́ \pi \rho \alpha \sigma o \varsigma$, which is chrysoprase with a light green colour, a variety of compact quartz as discussed above.

Brown et al. (1979:656) identified the term stone, but are unsure of its identification, suggesting 'perhaps ruby or carbuncle'. Clines (2001:715, 2009:278) identified the term as 'turquoise, garnet, or other (semi-)precious stone associated with the wealth of Tyre Ezek 27:16'. Köhler and Baumgartner (2001:709) identified it only as a green-coloured semi-precious stone, and then list proposals by other authors, namely turquoise, malachite or garnet. Noonan (2019:153) suggested turquoise on the basis of Egyptian etymology; however, the identification of the Egyptian term $m f k 3 t$ as turquoise or malachite is still a matter of debate (Aston, Harrell \& Shaw 2000:44). Lisowsky ([1958]1993:938) suggested malachite.

In the breastpiece of the high priest as well as the covering of the king of Tyre, the gem is translated with ö $v \theta \rho \alpha \xi$. The term $\alpha v \theta \rho \alpha \xi$ may refer to coal, charcoal or a burning coal as in Romans 12:20 quoting Proverbs 25:22 (the Hebrew term is לân $)$; this is its only use in the New Testament. These cases in the Septuagint are not considered (e.g. LXX Sir 8:10). The Septuagint $\alpha \hat{\alpha} v \rho \alpha \xi$ is translated in Latin as carbunculus (a small piece of coal), which is then loaned via French carbuncle into English (Hoad 1986:18; McKean 2005:1024). The Latin word had two main metaphorical meanings, based on the idea of a glowing coal: 'red gem' and 'red inflamed spot' (Ayto 1990:28, 97).

As a precious stone in classical and Septuagint Greek, the lexicographers list its meaning as 'carbuncle, ruby and garnet' (Liddell et al. 1968:141; Lust et al. 2003:50; Montanari 2015:178; Muraoka 2009:52), or 'garnet' (Chamberlain 2011:14). As indicated above, the term carbuncle for anthrax is known in late Middle English through Late Latin carbuncle (Hoad 1986:18; McKean 2005:1024) and is therefore too late to function in this context. 'Ruby' was not known at all in the ancient Near East or by the Greeks and Romans (Medieval Latin has for the first time the term lapis rubinus) (McKean 2005:1480). This leaves us with three possibilities to consider for the identification of $\alpha v \theta \rho \alpha \xi /$ İ⿴囗十 They are garnet, turquoise and malachite.

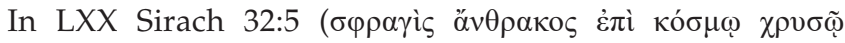

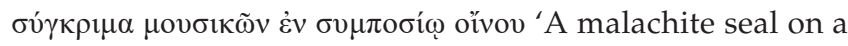
gold ornament is a concert of music at a banquet of wine'), the term $\alpha 2 v \theta \rho \alpha \xi$ typifies the material of a seal. In LXX Tobit

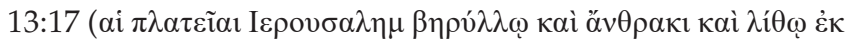

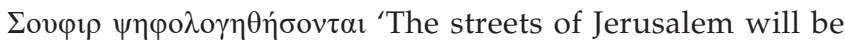
paved with beryl and malachite and stones of Ophir') the term $\alpha v \theta \rho \alpha \xi$ refers to a type of paving stone. In the LXX, when the term $\alpha \nu \theta \rho \alpha \xi$ refers to a stone, but does not translate נפכָ it may translate a variety of terms. In LXX Isaiah 54:11, $\alpha v \theta \rho \alpha \xi$ translates may refer to a red-pigment or a hand mortar, although it is also possible that in this verse
(Köhler \& Baumgartner 2001:918, similarly Brown et al.

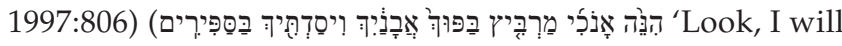
lay malachites as your building stones and make your

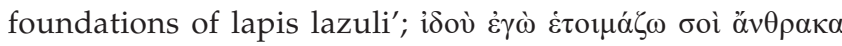

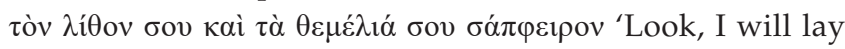
malachites as your building stones and make your foundations of lapis lazuli'). In MT Ezekiel 10:9, the phrase as the appearance of the stone of chrysolite' is used to describe the appearance of the wheels around the cherubim; the LXX translates $\omega \varsigma$ ó $\psi 1 \varsigma \lambda i$ i ov ơv $\theta \rho \alpha \kappa o \varsigma$ 'as the appearance of the stone of anthrax/malachite'. In Genesis

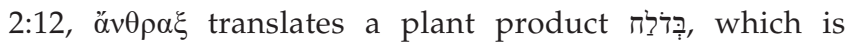
probably 'bdellium' (Brown et al. 1997:95), 'the odoriferous transparent yellowsish gum of a South Arabian tree, Commipora mukul Engler' (Köhler \& Baumgartner 2001:110).

From the usages of the term, it is clear that the precious stone under discussion must be suitable as a gem and seal, as well as for building materials, namely tiles and building stones.

Garnet is a general term to refer to any member of a group of common silicate minerals that have similar crystal structures and chemical compositions (Bauer 1968:345-347). They may be colourless, black and many shades of red and green (Bauer 1968:348). They occur in only small amounts, but are extensively used as gems since ancient times (Bauer 1968:345). As garnets are not really used as building material, an identification of $\alpha \nu \theta \rho \alpha \xi$ / נִפקָ with garnet is less plausible.

Turquoise (the mineral name is calaite) is always opaque, usually of a green or blue colour, belongs to the phosphates and is extensively used as a gemstone (Bauer 1968:389). It is a secondary mineral deposited from circulating waters, and it occurs chiefly in arid environments as blue to greenish, waxy veinlets in alumina-rich, weathered, volcanic or sedimentary rocks (Bauer 1968:398-392). Turquoise was obtained from the Sinai Peninsula before the 4th millennium BC in one of the world's first important hard-rock mining operations (Bauer 1968:396-397). It may be carved or engraved, and pieces are often set in mosaics (Bauer 1968:392). As turquoise is not really used as building

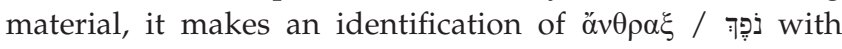
turquoise less plausible.

Malachite (Afrikaans: malagiet), a brilliant green copper carbonate mineral, which sometimes occurs distinctly crystallised, is used as inlay in jewellery as well as for larger ornament like bowls (Bauer 1968:524, 526; see Lucas \& Harris 1999:399 for a list of items from ancient Egypt). It is large enough to be used as a paving and building material in the form of thin plates of veneer, for example in the Isaac Church of St Petersburg in modern times (Bauer 1968:526). Bauer (1968:526) stated that the uses to which malachite is applied are very similar to those of lapis lazuli. Malachite is thus the

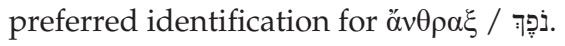




\section{Conclusion}

In this article, we have demonstrated how editorial theory and complexity thinking provide powerful methodologies for the etymology and identification of precious stones in the Bible. The Septuagint translation of the names for precious stones provides invaluable information concerning the identity of the precious stones in the Hebrew Bible. The Septuagint's pivotal role stems from two facts. Firstly, the Septuagint is the oldest translation of the Hebrew Bible and thus provides the earliest translation indicating how the translators understood the Hebrew terms. Secondly, there were important and detailed analytical works on stones in Greek (Theophrastus' On Stones and Pliny the Elder's Naturalis Historia), which described the stones and their physical characteristics. Based upon the analysis in the preceding sections, the identification of the precious stones in the breastpiece of the high priest can be summarised in Table 3.

TABLE 3: Identification of the precious stones in the breastpiece of high priest.

\begin{tabular}{|c|c|c|c|}
\hline & $\begin{array}{l}\text { MT-Exodus 28:17-20 } \\
\text { MT-Exodus 39:10-14 }\end{array}$ & $\begin{array}{l}\text { LXX-Exodus } \\
\text { [stones in MT order] }\end{array}$ & Identification \\
\hline \multirow[t]{3}{*}{ Row 1} & אדָׁ & 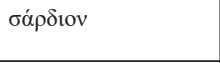 & $\begin{array}{l}\text { Carnelian or sardius with a } \\
\text { reddish colour }\end{array}$ \\
\hline & 政 & 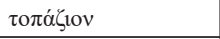 & Topaz with a yellow colour \\
\hline & בדרְקתות & 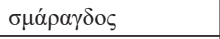 & Emerald with a green colour \\
\hline \multirow[t]{4}{*}{ Row 2} & נפקֶּ & $\ddot{v} \theta \rho \alpha \xi$ & $\begin{array}{l}\text { Malachite with a dark green } \\
\text { colour }\end{array}$ \\
\hline & סַפְּיר & 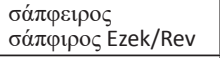 & $\begin{array}{l}\text { Lapis lazuli with a dark blue } \\
\text { colour }\end{array}$ \\
\hline & אידהלםם & & $\begin{array}{l}\text { Aquamarine, a type of beryl, } \\
\text { with a turquoise colour }\end{array}$ \\
\hline & & $\beta \eta \rho v ́ \lambda \lambda ı v$ & $\begin{array}{l}\text { Beryl with a blue-green } \\
\text { colour }\end{array}$ \\
\hline \multirow[t]{3}{*}{ Row 3} & לֶשֶׁם & $\lambda$ ıүúpıov & $\begin{array}{l}\text { Hyacinth with an orange } \\
\text { colour }\end{array}$ \\
\hline & שֶׁבוֹ & $\grave{\alpha} \chi \alpha ́ \alpha \eta \zeta$ & $\begin{array}{l}\text { Agate multicoloured with } \\
\text { white stripes }\end{array}$ \\
\hline & 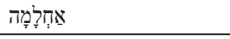 & 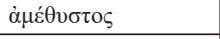 & Amethyst with purple colour \\
\hline \multirow[t]{3}{*}{ Row 4} & תמרְּשישׁ & $\chi \rho v \sigma o ́ \lambda_{\imath} \theta$ os & $\begin{array}{l}\text { Chrysolite (peridot) with } \\
\text { yellow-green colour (belongs } \\
\text { to olivine mineral group) }\end{array}$ \\
\hline & שَהِם & 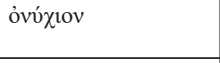 & $\begin{array}{l}\text { Onyx with black or dark grey } \\
\text { colour with white stripes }\end{array}$ \\
\hline & 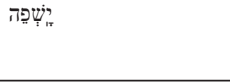 & $i \alpha \sigma \pi \iota \varsigma$ & $\begin{array}{l}\text { Jasper with brownish-red } \\
\text { colour (late Hellenistic jasper is } \\
\text { green) }\end{array}$ \\
\hline
\end{tabular}

MT, Masoretic Text; LXX-Exodus, Septuagint-Exodus.

TABLE 4: New stones in Revelation 21:19-20 in relation to LXX lists.

\begin{tabular}{|c|c|c|c|}
\hline \multicolumn{2}{|c|}{ LXX stone and identification } & \multicolumn{2}{|c|}{$\begin{array}{l}\text { Substitute stone in Revelation 21:19-20 and } \\
\text { its identification }\end{array}$} \\
\hline$\alpha{ }^{2} v \rho \rho \xi$ & $\begin{array}{l}\text { Malachite with a dark } \\
\text { green colour }\end{array}$ & $\chi \rho v \sigma o ́ \pi \rho \alpha \sigma o \varsigma$ & $\begin{array}{l}\text { Chrysoprase with a light } \\
\text { green colour, a variety of } \\
\text { compact quartz }\end{array}$ \\
\hline$\lambda$ เүúpıov & $\begin{array}{l}\text { Hyacinth with an orange } \\
\text { colour ( } \lambda \text { ivóptov is a very } \\
\text { rare name) }\end{array}$ & vंókıv $\theta$ os & $\begin{array}{l}\text { Hyacinth (same stone as } \\
\lambda \text { lyv́ptov in LXX but a } \\
\text { different name) }\end{array}$ \\
\hline$\dot{\alpha} \chi \alpha \dot{\alpha} \tau \eta \varsigma$ & $\begin{array}{l}\text { Agate multicoloured with } \\
\text { white stripes (fell out of } \\
\text { favour in Roman era and } \\
\text { decreased in value) }\end{array}$ & $\chi \alpha \lambda \kappa \eta \delta \omega ́ v$ & $\begin{array}{l}\text { Chalcedony, a milk white } \\
\text { stone, similar in appearance } \\
\text { to an agate but without } \\
\text { stripes (valued in } \\
\text { Roman era) } \\
\end{array}$ \\
\hline ỏvóxıv & $\begin{array}{l}\text { Onyx with black/dark grey/ } \\
\text { red/brown colour with } \\
\text { white stripes (broad term } \\
\text { before Imperial Roman } \\
\text { era; after the Roman era it } \\
\text { refers only to a black/grey } \\
\text { stone) }\end{array}$ & $\sigma \alpha \rho \delta o ́ v v \xi$ & 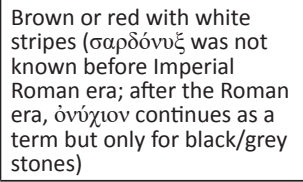 \\
\hline
\end{tabular}

LXX, Septuagint
As demonstrated above, there is referential identity between the Hebrew term and its Greek equivalent except in the case of יָּהלם (aquamarine), which the Septuagint translator(s) rendered with the closest equivalent known to him $\beta \eta \rho v i \lambda \lambda$ เov (beryl), a blue-green stone in the same mineral family as the aquamarine.

In line with lexicographical research in progress (Aitken 2014; Lee 2012), our future research will refine the results of the above identification of precious stones by taking evidence provided by the documentary sources (papyri and inscriptions) into account, which is outside the scope of this article.

Amongst the important findings of the research are the following. In general, the Septuagint must be understood as a translation; the translators chose terms for translating the precious stones to suit their purposes in the particular passage and in accordance with the inventory of precious stones that were known to them and valued by them. By taking into account the full range of the history of the terms for precious stones, it is possible to show where the referents of terms have changed, where a stone with a similar appearance is substituted for another stone and how to explain the different renderings of terms in the various translations. The Septuagint, as the earliest translation of the Hebrew Bible, provides the earliest information concerning the identification and interpretation of the precious stones. The translators' strategies of re-ordering, normalising and substitution assist us in knowing their viewpoints with respect to the identification of the stones, their valuation as precious stones and their symbolic values. ${ }^{4}$ The Septuagint translation of the precious stones in the breastpiece of the high priest is the Rosetta Stone for understanding all of the precious stones in the Hebrew Bible and the New Testament.

\section{Acknowledgements}

An earlier version of this article was presented at the Southern African Society for Ancient Near Eastern Studies at the University of KwaZulu-Natal, Pietermaritzburg, South Africa on 16 September 2019. We are grateful for the comments of participants at the conference, especially Prof. Boaz Zissu. We also thank Megan Welman Purchase of the Department of Geology at the University of the Free State for her assistance with the scientific identification of the stones discussed in the article.

\section{Competing interests}

The authors declare that they have no financial or personal relationships that may have inappropriately influenced them in writing this research article.

\section{Authors' contributions}

J.A.N. and C.L.M-N. contributed equally to this research article.

4.The symbolic values of the precious stones in the breastpiece of the high priest as translated in the LXX are discussed in Miller-Naudé and Naudé (2020). 


\section{Ethical considerations}

This article followed all ethical standards for research without direct contact with human or animal subjects.

\section{Funding information}

This work is based on the research supported in part by the National Research Foundation of South Africa (Jacobus A. Naudé UID 85902 and Cynthia L. Miller-Naudé UID 95926). The grantholders acknowledge that the opinions, findings and conclusions or recommendations expressed in any publication generated by the NRF-supported research are those of the authors, and that the NRF accepts no liability whatsoever in this regard.

\section{Data availability}

Data sharing is not applicable to this study as no new data were created or analysed in this study.

\section{Disclaimer}

The views and opinions expressed in this article are those of the authors and do not necessarily reflect the official policy or position of any affiliated agency of the authors.

\section{References}

Abbott-Smith, G., 1937, A manual Greek lexicon of the New Testament, T\&T Clark, Edinburgh.

Aitken, J.K., 2014, No stone unturned: Greek inscriptions and Septuagint vocabulary, Eisenbrauns, Winona Lake, IN.

Alcalay, R., 1963-1965, The complete Hebrew-English dictionary, Massada Publishing, Ramat-Gan.

Aldred, C., 1978, Jewels of the Pharaohs: Egyptian jewelry of the Dynastic Period, Ballantine Books, New York, NY.

Arndt, W.F. \& Gingrich, FW. 1957, A Greek-English lexicon of the New Testament and other early Christian literature, The University of Chicago Press, Chicago, IL.

Aston, B., Harrell, J.A. \& Shaw, I., 2000, 'Stone', in Ancient Egyptian materials and technology, pp. 5-77, Cambridge University Press, Cambridge.

Ayto, J. 1990, Dictionary of word origins, Arcade Publishing, New York, NY.

Bahrani, Z., 1995, 'Jewelry and personal arts in ancient Western Asia', in J. Sasson (ed.), Civilizations of the Ancient Near East, pp. 1635-1645, Hendrickson Publishers, Peabody, MA.

Barr, J., 1961, The semantics of biblical language, Oxford University Press, London.

Bauer, M., 1968, Precious stones, Dover Publications, New York, NY.

Bauer, F., Danker F.W., Arndt, W.F. \& Gingrich, F.W. (eds.), 2000, Greek-English Lexicon of the New Testament and Other Early Christian Literature, 3rd edn., University of of the New Testament and
Chicago Press, Chicago, IL.

Bostock, J. \& Riley, H.T., 1857, The natural history of Pliny: Translated with copious notes and illustrations, vol. 6, Henry G. Bohn, London.

Brown, F., Driver, S.R. \& Briggs, C.A., 1979, The new Brown-Driver-Briggs-Gesenius Hebrew and English lexicon with an appendix containing the Biblical Aramaic, Hendrickson, Peabody, MA.

Caley, E.A. \& Richards, J.F.C., 1956, Theophrastus on Stones: Introduction, Greek text, English translation, and commentary, Ohio State University, Columbus, $\mathrm{OH}$.

Chamberlain, G.A., 2011, The Greek of the Septuagint: A supplemental lexicon, Hendrickson, Peabody, MA.

Clines, D.J.A. (ed.), 1993, The dictionary of Classical Hebrew, vol. 1, Sheffield Academic Press, Sheffield.

Clines, D.J.A. (ed.), 1994, The dictionary of Classical Hebrew, vol. 2, Sheffield Academic Press, Sheffield.

Clines, D.J.A. (ed.), 1998, The dictionary of Classical Hebrew, vol. 4, Sheffield Academic Press, Sheffield.

Clines, D.J.A. (ed.), 2001, The dictionary of Classical Hebrew, vol. 5, Sheffield Academic Press, Sheffield.

Clines, D.J.A. (ed.), 2009, The concise dictionary of Classical Hebrew, Sheffield Academic Press, Sheffield.

Clines, D.J.A. (ed.), 2011, The dictionary of Classical Hebrew, vol. 8, Sheffield Academic Press, Sheffield.
Clines, D.J.A. (ed.), 2018, The dictionary of Classical Hebrew revised, Vol. 1, Sheffield Academic Press, Sheffield.

Cooper, C.W., 1928, 'A jasper stone, clear as crystal', The Churchmen 42(1), 47-50.

Crystal, D., 1997, The Cambridge encyclopedia of language, 2nd edn., Cambridge University Press, Cambridge.

Diringer, D., 1958, 'Seals', in D. Winton Thomas (ed.), Documents from Old Testament times, pp. 218-226, Harper \& Brothers, New York, NY.

Ellis, N.C. \& Larsen-Freeman, D. (eds.), 2009, Language as a complex adaptive system, Blackwell, Oxford.

Encyclopædia Britannica, 2006, 'Emerald', Encyclopædia Britannica 2006 Ultimate Reference Suite DVD, Encyclopædia Britannica, Inc., Chicago, IL.

Encyclopædia Britannica, 2006, 'Malachite', Encyclopædia Britannica 2006 Ultimate Reference Suite DVD, Encyclopædia Britannica, Inc., Chicago, IL.

Encyclopædia Britannica, 2006, 'Topaz', Encyclopædia Britannica 2006 Ultimate Reference Suite DVD, Encyclopædia Britannica, Inc., Chicago, IL.

Fensham, F.C., 1971, 'Problems in connection with translation of ancient texts', in I.H. Eybers, F.C. Fensham, C.J. Labuschagne, W.C. Van Wyk \& A.H. Van Zyl (eds.), De Fructu Oris Sui: Essays in honour of Adrianus van Selms, pp. 46-57, Pretoria Oriental Series 9, E.J. Brill, Leiden.

Gesenius, W., 1847, Lexicon manuale Hebraicum et Chaldaicum in Veteris Testament Libros, Sumtibus Fr. Chr. Guil. Vogelii, Lipsiae.

Gove, P.B., 1966, Webster's third new international dictionary of the English language unabridged, William Benton, Chicago, IL.

Harrell, J.A., 2011, 'Old Testament gemstones: A philological, geological, and archaeological assessment of the Septuagint', Bulletin for Biblical Research 21(2), 141-172.

Harrell, J.E., Hoffmeier, J.K. \& Williams, K.F., 2017, 'Hebrew gemstones in the Old Testament: A lexical, geological, and archaeological analysis', Bulletin for Biblical Research 27(1), 1-52.

Hatch, E. \& Redpath, H.A., 1998/1902, A concordance to the Septuagint and the other Old Greek versions of the Old Testament, At the Clarendon Press, Oxford.

Hoad, T.F. (ed.), 1986, Concise dictionary of English etymology, Oxford University Press, Oxford.

Horsley, G.H.R., 1984, 'Divergent views on the nature of the Greek of the Bible', Biblica 65, 393-403.

Jastrow, M., 1967, A dictionary of the Targumim, the Talmud Babli and Yerushalmi, and the midrashic literature, Shalom Pub Ind, Brooklyn, NY.

Köhler, L., 1937, 'Hebräische Vokabeln II', Zeitschrift für die alttestamentliche Wissenschaft 55, 161-174. https://doi.org/10.1515/zatw.1937.55.1-2.161

Köhler, L. \& Baumgartner, W. (eds.), 1953, Lexicon in Veteris Testamenti Libros, Brill, Leiden.

Köhler, L. \& Baumgartner, W. (eds.), 1958, Lexicon in Veteris Testamenti Libros, 2nd edn., Brill, Leiden.

Köhler, L. \& Baumgartner, W. (eds.), 1967, Hebräisches und Aramäisches Lexikon zum Alten Testsament, 3rd edn., Brill, Leiden.

Köhler, L. \& Baumgartner, W. (eds.), 2001, The Hebrew and Aramaic lexicon of the Old Testament, Brill, Leiden.

Landau, S.I., 2001, Dictionaries: The art and craft of lexicography, 2nd edn., Cambridge University Press, Cambridge.

Larsen-Freeman, D. \& Cameron, L., 2008, Complex systems and applied linguistics, Oxford University Press, Oxford.

Le Boulluec, A. \& Sandevoir, P. (eds.), 2004, La Bible D'Alexandrie: L'Exode, Éditions du Cerf, Paris.

Lee, J.A.L., 2004. 'The present state of lexicography of ancient Greek', in B. Taylor, J. Lee, P. Burton \& R. Whitaker (eds.), Biblical Greek language and lexicography: Essays in honor of Frederick W. Danker, pp. 66-74, Eerdmans, Grand Rapids, MI.

Lee, J.A.L., 2010, 'Review of Muraoka, T., 2009, 'A Greek-English lexicon of the Septuagint, Peeters, Louvain, Paris, Walpole, $M A^{\prime}$, Bulletin of the International Organization for Septuagint and Cognate Studies 43, 117-127.

Lee, J.A.L., 2012, 'The Septuagint and the vocabulary of the Papyri', Proceedings of Royal Flemish Academy of Belgium for Science and the Arts, Brussels Contact Forum, Brussels.

Lewis, C. \& Short, C., [1879] 1945, A Latin dictionary founded on Andrew's Edition of Freund's Latin dictionary, rev. edn., Clarendon Press, Oxford.

Liddell, H.G. \& Scott, R., [1871] 1976, A lexicon abridged from Liddell and Scott's Greek-English lexicon, Clarendon Press, Oxford.

Liddell, H.G., Scott, R. \& Jones, H.S. (eds.), 1968, A Greek-English lexicon, Clarendon Press, Oxford.

Lied, L.I. \& Lundhaug, H. (eds.), 2017, Snapshots of evolving traditions: Jewish and Christian manuscript culture, textual fluidity and new philology, Texte und Untersuchungen zur Geschichte der altchristlichen Literatur 175, Walter de Gruyter, Berlin.

Lisowsky, G., [1958] 1993, Konkordanz zum Hebräischen Alten Testament, Deutsche Bibelgesellschaft, Stuttgart.

Louw, J.P. \& Nida, E.A., 1988, Greek-English lexicon of the New Testament based on semantic domains, vol. 1, United Bible Societies, New York, NY.

Lucas, A. \& Harris, J.R., 1999, Ancient Egyptian materials and industries, 4th rev. edn., Dover Publications, Mineola, NY. 
Lust, J., Eynikel, E. \& Hauspie, K., 2003, A Greek-English lexicon of the Septuagint, rev. edn., Deutsche Bibelgesellschaft, Stuttgart.

Magnus, A., 1967, Book of minerals, transl. D. Wyckoff, Clarendon Press, Oxford.

Marais, K., 2014, Translation theory and development studies: A complexity theory approach, Routledge Advances in Translation Studies, Routledge, London.

McKean, E. (ed.), 2005, The new Oxford American dictionary, 2nd edn., Oxford University Press, Oxford.

Miller-Naudé, C.L. \& Naudé, J.A., 2018, 'Editorial theory and the range of translations for "cedars of Lebanon" in the Septuagint', HTS Teologiese Studies/Theological for "cedars of Lebanon" in the Septuagint', HTS Teologiese Stu
Studies 74(3), a5059. https://doi.org/10.4102/hts.v74i1.5059

Miller-Naudé, C.L. \& Naudé, J.A., 2020, 'Textual interrelationships involving the Septuagint translations of the precious stones in the breastpiece of the high priest', HTS Teologiese Studies/Theological Studies 76(4), a6141. https://doi. org/10.4102/hts.v76i4.6141

Montanari, F., 2015, The Brill dictionary of ancient Greek, Harvard University, Brill, Leiden.

Mühlau, F. \& Volck, W., 1878, Wilhelm Gesenius' Hebräisches und Chaldäisches Handwörterbuch über das Alte Testament, Achte Auflage neu bearbeitet FCW Vogel, Leipzig.

Muraoka, T., 2009, A Greek-English lexicon of the Septuagint, Peeters, Louvain, Paris, Walpole, MA

Naudé, J.A. \& Miller-Naudé, C.L., 2018, 'Lexicography and the translation of "cedars of Lebanon" in the Septuagint', HTS Teologiese Studies/Theological Studies 74(3) a5042. https://doi.org/10.4102/hts.v74i3.5042

Naudé, J.A. \& Miller-Naudé, C.L., 2019, 'Sacred writings and their translations as complex phenomena: The Book of Ben Sira in the Septuagint as a case in point', in K. Marais \& R. Meylaerts (eds.), Complexity thinking in translation studies: K. Marais \& R. Meylaerts (eds.), Complexity thinking in translation
Methodological considerations, pp. 180-215, Routledge, New York, NY.

Naudé, J.A., \& Miller-Naudé, C.L. forthcoming, 'Biblical plant hermeneutics and the translation of plants and plant products in the Book of Ben Sira 24:13-17', in P.S. Marshall, J.D. Meade \& J.M. Kiel (eds.) Like nails firmly fixed: Essays on the text and language of the Hebrew and Greek Scriptures, Peeters, Leuven.

Naudé, J.A., Miller-Naudé, C.L., \& Makutoane, T.J., forthcoming, 'The metaphorical and symbolic uses of flora in the Bible: Identification and translation of "hyssop"", in P. Machinist, R. Harris, J. Berman, N. Samet \& N.A. Darshan (eds.) Ve-PEd Yasaleh (Gen 2:6), Writings from the Ancient World, Scholars Press, Atlanta, GA.

Noonan, B.J., 2019, Non-Semitic loanwords in the Hebrew Bible: A lexicon of language contact, Linguistic Studies in Ancient West Semitic, 14, Eisenbrauns, University Park, PA

Payne Smith, J., 1903, A compendious Syriac dictionary, Clarendon Press, Oxford.

Pickett, J.P., (ed.), 2002, The American heritage college dictionary, 4th edn., Houghton Mifflin Company, Boston, MA

Platt, E.E., 2003, 'Jewelry in the levant', in S. Richard (ed.), Near Eastern archaeology: A reader, pp. 197-204, Eisenbrauns, Winona Lake, IN

Platt, E.E., 2006, 'Amber', in K.D. Sakenfeld (ed.), The new interpreter's dictionary of the Bible, vol. 1, p. 129, Abingdon, Nashville, TN.

Platt, E.E., 2007, 'Diamond', in K.D. Sakenfeld (ed.), The new interpreter's dictionary of the Bible, vol. 2, p. 120, Abingdon, Nashville, TN.

Quiring, H., 1954, 'Die Edelsteine im Amtsschild des jüdischen Hohepriesters und die Herkunft ihrer Namen', Sudhoffs Archiv für Geschichte der Medizin und der Naturwissenschaften 38, 193-213.

Reader, W.W., 1981, 'The twelve jewels of Revelation 21:19-20', Journal of Biblical Literature 100(3), 433-457. https://doi.org/10.2307/3265963

Robinson, E., 1871, Hebrew and English lexicon of the Old Testament including the Biblical Chaldee from the Latin of William Gesenius with corrections and large additions, partly furnished by the author in manuscript, and partly condensed from his larger thesaurus, as completed by Roediger, 20th edn., revised and stereotyped, Crocker \& Brewster, Boston, MA

Romano, J.F., 1995, 'Jewelry and personal arts in ancient Egypt', in J. Sasson (ed.), Civilizations of the Ancient Near East, pp. 1605-1621, Hendrickson Publishers, Peabody, MA.
Sokoloff, M., 2002, A dictionary of Jewish Palestinian Aramaic, 2nd edn., Bar llan University Press, Ramat-Gan, Israel / The Johns Hopkins University Press, Baltimore, MD.

Sokoloff, M., 2009, A Syriac lexicon: A translation from the Latin, correction, expansion, and update of C. Brockelmann's Lexicon Syriacum, Eisenbrauns and Gorgias Press, Pistcataway, NJ.

Taylor, B.A., 2009, Analytical lexicon to the Septuagint, Hendrickson Publishers, Peabody, MA.

Theophrastus, [1916] 1999, Enquiry into plants, Books 1-V with an English translation by Arthur Hort, Harvard University Press, Cambridge, MA.

Walters, P., 1973, The text of the Septuagint: Its corruptions and their emendation Cambridge University Press, Cambridge.

Winer, G.B., 1828, Lexicon Manuale Hebraicum et Chaldaicum in Veteris Testamentti Libros ordine etymologico descritum, Apud Fridericum Fleischer, Lipsiae.

\section{Biblical texts and versions}

Aland, B., Aland, K., Karavidopoulos, J., Martini, C.M. \& Metzger, B.M., 2012, Novum Testamentum Graece, 28th revised edn., Deutsche Bibelgesellschaft, Stuttgart.

Clarke, E.G., 1984, Targum Pseudo-Jonathan to the Pentateuch: Text and Concordance, Ktav, Hoboken, NJ.

Cohen, M., 1992, מקראות גדולות הכתר, Bar Ilan University Press, Ramat Gan.

Comprehensive Aramaic Lexicon Project, Hebrew Union College, Cincinnati, viewed 12 April 2020, from http://cal.huc.edu.

Elliger, K. \& Rudolph, W., (eds.), 1997, Biblia Hebraica Stuttgartensia, 1997, Deutsche Bibelgesellschaft, Stuttgart.

Hanhart, R., 1979, Septuaginta: Vetus Testamentum Graecum, Judith Vol. VIII, 4 Akademie der Wissenschaften im Göttingen, Vandenhoeck \& Ruprecht, Göttingen.

Hanhart, R., 1983, Septuaginta: Vetus Testamentum Graecum, Tobit Vol. VIII, 5 Akademie der Wissenschaften im Göttingen, Vandenhoeck \& Ruprecht, Göttingen.

Levy, B.B., 1986, Targum Neophyti 1: A textual study, University Press of American, Lanham, MD.

Mulder, M.J. (ed.), 1993, The Old Testament in Syriac according to the Peshitta Version, Part III Fasc. 3. Ezekiel, Peshịtta Institute, Brill, Leiden.

Rahlfs, A., 2008, Septuaginta: Vetus Testamentum Graecum, Psalmi cum Odis, vol. 10, Akademie der Wissenschaften im Göttingen, Vandenhoeck \& Ruprecht, Göttingen.

Rahlfs, A. \& Hanhart, R. (eds.), 2006, Septuaginta: Id est Vetus Testamentum Graece iuxta LXX interpretes, rev. edn., Deutsche Bibelgesellschaft, Stuttgart.

Sperber, A., 1992a, The Bible in Aramaic: The Latter Prophets according to Targum Jonathan, Brill, Leiden.

Sperber, A., 1992b, The Bible in Aramaic: The Pentateuch according to Targum Onkelos, Brill, Leiden.

Ter Haar Romeny, B. \& Van Peursen, W. Th. (eds.), 2016, The Old Testament in Syriac according to the Peshitta Version, Part 1 Fasc. 1. Preface-Genesis; Exodus, Peshitta Institute, Brill, Leiden.

Weber, R. \& Gryson, R. (eds.), 2007, Biblia Sacra: luxta Vulgatam Versionem, 5th edn Deutsche Bibelgesellschaft, Stuttgart.

Wevers, J.W., 1974-1991, Septuaginta: Vetus Testamentum Graecum, Pentateuch, Akademie der Wissenschaften in Göttingen, Vandenhoeck \& Ruprecht, Göttingen.

Ziegler, J., 1965, Septuaginta: Vetus Testamentum Graecum, Sapientia lesu Filii Sirach, vol. 12, no. 2, Akademie der Wissenschaften im Göttingen, Vandenhoeck \& Ruprecht, Göttingen.

Ziegler, J., 1982, Septuaginta: Vetus Testamentum Graecum, lob, vol. 11, no. 4 Akademie der Wissenschaften im Göttingen, Vandenhoeck \& Ruprecht, Göttingen.

Ziegler, J., 1983, Septuaginta: Vetus Testamentum Graecum, Isaias, vol. 14, Akademie der Wissenschaften im Göttingen, Vandenhoeck \& Ruprecht, Göttingen.

Ziegler, J., 2006, Septuaginta: Vetus Testamentum Graecum, Ezekiel, vol. 16, no. 1 Akademie der Wissenschaften im Göttingen, Vandenhoeck \& Ruprecht, Göttingen. 